\title{
Promoting sustainable human development in engineering: Assessment of online courses within continuing professional development strategies
}

\author{
Agustí Pérez-Foguet ${ }^{\text {a, b }}$, Boris Lazzarini ${ }^{\text {b, c, * }}$, Ricard Giné ${ }^{\text {a, b }}{ }^{\text {, Enrique Velo }}{ }^{\text {b, d }}$, \\ Alejandra Boni ${ }^{\mathrm{e}}$, Manuel Sierra ${ }^{\mathrm{f}}$, Guido Zolezzi $^{\mathrm{g}}$, Rhoda Trimingham ${ }^{\mathrm{h}}$

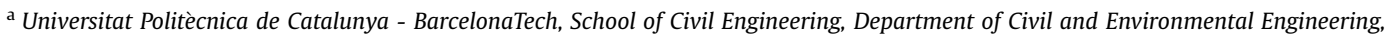 \\ c/ Jordi Girona 1-3, Ed, C2, 08034 Barcelona, Spain \\ ${ }^{\mathrm{b}}$ Universitat Politècnica de Catalunya-BarcelonaTech, Engineering Sciences and Global Development (ESc\&GD), Barcelona, Spain \\ ${ }^{c}$ Universitat Politècnica de Catalunya- BarcelonaTech, Research Institute of Sustainability Science and Technology, c/ Jordi Girona 31, \\ Ed. TG - S1, 08034, Barcelona, Spain \\ ${ }^{\mathrm{d}}$ Universitat Politècnica de Catalunya- BarcelonaTech, School of industrial Engineering, Department of Heat Engines, Avda. Diagonal 647, \\ Ed. H, 08028, Barcelona, Spain \\ ${ }^{e}$ Universitat Politècnica de València, INGENIO (CSIC-UPV), Ed. 5J, Camino Vera s/n, 46022, Valencia, Spain \\ ${ }^{\mathrm{f}}$ Universidad Politécnica de Madrid, ETSI Telecomunicación, Av. Complutense, 30, 28040, Madrid, Spain \\ ${ }^{g}$ Universitá degli Studi di Trento, UNESCO Chair in Engineering for Human and Sustainable Development - DICAM, via Mesiano, 77, 38123, Trento, Italy

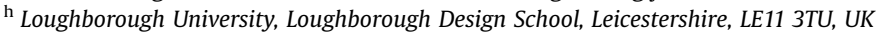

\section{A R T I C L E I N F O}

\section{Article history:}

Received 8 July 2016

Received in revised form

15 May 2017

Accepted 30 June 2017

Available online $\mathrm{xxx}$

Handling Editor: R.L. Lozano

\section{Keywords:}

Sustainable human development

Engineering

Global dimension

Continuing professional development

\begin{abstract}
A B S T R A C T
Higher Education Institutions play a critical role in societies transition towards sustainable development, educating future professionals and decision makers. In the last few decades, a number of technical universities have devoted major efforts to integrating sustainable development into engineering curricula. There is still, however, an increasing need to further transform learning and training environments and build capacity of educators and trainers on sustainable development issues.

Against this background, this paper assesses the role of online training courses, within continuing professional development strategies, in promoting sustainable human development in engineering degrees. It was built upon the implementation of a European initiative, the Global Dimension in Engineering Education, promoted by a transdisciplinary consortium of technical universities and nongovernmental organisations.

In terms of method, this study analyses two sets of quantitative and qualitative indicators to assess i) the perceived quality/relevance of the training proposals, and ii) the learning acquisition of participants. Quantitative indicators were complemented by a descriptive analysis of findings from a semi-structured survey. The results provide evidence that online learning can be an effective approach for continuing professional development of academics. The findings also suggest that participants perceived online courses' contents and curricula, developed jointly by academics and practitioners of non-governmental organisations, as relevant and useful for integrating sustainability principles in teaching activities. To conclude, authors recommend the leaders of higher educational institutions to explore the integration of online courses addressed to faculty into university policy and strategies, as a way to promote professional development and the engagement of academics on sustainable development.
\end{abstract}

() 2017 Elsevier Ltd. All rights reserved.
* Corresponding author. Universitat Politècnica de Catalunya- BarcelonaTech, Research Institute of Sustainability Science and Technology, c/ Jordi Girona 31, Ed. TG - S1, 08034, Barcelona, Spain.

E-mail addresses: agusti.perez@upc.edu (A. Pérez-Foguet), boris.lazzarini@upc edu (B. Lazzarini), ricard.gine@upc.edu (R. Giné), enrique.velo@upc.edu (E. Velo), aboni@dpi.upv.es (A. Boni), manuel.sierra@upm.es (M. Sierra), guido.zolezzi@ unitn.it (G. Zolezzi), R.L.Trimingham@lboro.ac.uk (R. Trimingham).

\section{Introduction}

The early years of this decade have seen increased political will in relation to sustainable development issues. The considerable political support for the Millennium Development Goals (United Nations, 2000) has added political impetus to the argument that there cannot be sustained progress towards the achievement of development goals without active and critically aware citizens in 


\section{Abbreviations not standard}

$\begin{array}{ll}\text { GDEE } & \text { Global Dimension in Engineering Education } \\ \text { GD } & \text { Global Dimension } \\ \text { VLP } & \text { Virtual Learning Platform } \\ \text { OSE } & \text { Online Student Engagement Scale }\end{array}$

Europe. This, along with strategic work by global and development advocates, has led to historical agreements such as the 2030 Agenda for Sustainable Development and its 17 Sustainable Development Goals (United Nations, 2015), and the Paris Convention on Climate Change (UNFCCC, 2015), which strengthens the link between climate and energy policies at both national and international level.

The most recognized definition of 'Sustainable Development' (SD) comes from the United Nations World Commission on Environment and Development in 1987, stating that "sustainable development is the development which meets the needs of the present without compromising the ability of future generations to meet their own needs" (WCED, 1987, p. 42). The different meanings of this generic definition of SD and its misconceptions have been discussed in academic literature (Filho, 2011, 2000).

Other development approaches, such as those based on Human Development (HD) and Sustainable Human Development (SHD), focus specifically on addressing global inequalities (extreme poverty, gender equality, human and civil rights, etc.), and the promotion of a more socially just world. HD and SHD approaches define development as a process of expansion of capabilities and real freedoms that people enjoy (Sen, 1999). The Human Development Reports (HDR) of the United Nations Development Program have institutionalised and operationalized the HD approach, by combining both aspects of development (sustainable and human) and, in the year 2011, by defining SHD as the "the expansion of the substantive freedoms of people today while making reasonable efforts to avoid seriously compromising those of future generations" (UNDP, 2011, p. 18). Theoretical boundaries between the concepts of SD and SHD are not clear and precise and thus present diverse possible interpretations (Absell, 2015). In this study, the concept of SHD is specifically used when highlighting the fulfilment of basic needs and the expansion of human capabilities within SD approaches.

Higher Education Institutions (HEIs) play a critical role in societies transition towards SD and SHD since they educate future practitioners and decision makers who will face important and complex decisions on environmental, social and political issues (Lozano et al., 2013). In the framework of the United Nations Decade of Education for Sustainable Development 2005-2014 (DESD), a number of countries devoted considerable efforts to promote the integration of the principles of Education for Sustainable Development (ESD) into all aspects of education (UNESCO, 2014), including higher education. With varying degrees of success among countries, it is worth highlighting some encouraging trends, such as: i) the reorientation of education programmes, at different levels, increasingly addressing and integrating sustainability issues; ii) the convergence between sustainable development agendas and education agendas; and iii) the increase of essential pedagogical innovation, such as whole-institution approaches towards ESD.

The DESD final report, however, also indicates that actual changes in curriculum and educators' practices, at all levels of education, have been slow and characterised by incremental advances, and more efforts are needed in order to properly institutionalise ESD in HEI. Among the priority actions identified in the final report for $\mathrm{HE}$ is the need to further transform learning and training environments and build capacity of educators and trainers (ibidem).

Recent scientific literature reaches similar conclusions (Lozano et al., 2015). More specifically, the implementation of SD competencies through teaching appears to be challenging in various ways. From one side, learning processes enabling changes depend to a large extent on academics and their capability and willingness to support transformative processes (Barth and Rieckmann, 2012). From the other side, various studies identify a number of barriers to change that persist and prevent lasting faculty engagement (Lozano, 2006; Velazquez et al., 2006; Verhulst and Lambrechts, 2014).

Engineering is widely recognized as a critical discipline to address SD challenges and contribute to a sustainable future (Davidson et al., 2010; Karatzoglou, 2013); and the impact of engineering on the achievement of Sustainable Development Goals (SDGs) is beyond question (Clifford and Zaman, 2016). In the same vein, international institutions recognise the impact that engineering has on societies, ethics and ones' individual value-base (UNESCO, 2010). Consequently, abundant literature reflects the increasing need for improving the connections between engineering and SD (Lozano and Lozano, 2014; Mulder et al., 2012; Rose et al., 2015).

Globalization of the higher education arena has also contributed to build momentum in this direction. It is essential to provide future engineers with skills and capabilities to enable them to exercise their profession in a globalized and changing society, and with appropriate approaches that support global needs (Boni et al., 2015). The effect of globalization on the development and practice of the engineering profession, alongside the increasing challenges of $\mathrm{SD}$, are calling for significant adaptations to the curriculum of engineering studies.

Over the last decade, technical universities and engineering faculties have been involved in embedding SD into their academic systems, improving teaching strategies (Boni and Pérez-Foguet, 2008; Mulder et al., 2015; Pérez-Foguet et al., 2005; Segalàs et al., 2010) and ensuring that the approach is incorporated into professional education (Boni and Pérez Foguet, 2006; Holmberg et al., 2008; Lozano and Lozano, 2014; von Blottnitz et al., 2015). However, a number of scholars highlight a lack of a proper understanding of the principles of SD among engineering students (Azapagic et al., 2005; Byrne et al., 2013; Segalàs et al., 2009).

The debate about which practices or processes can enable change at university level (Ferrer-Balas et al., 2010; Lozano et al., 2015; Pérez-Foguet, 2008; Pérez-Foguet and Cruz López, 2011; Ramos et al., 2015) and, specifically, in engineering education (Davidson et al., 2010; Mulder et al., 2012; von Blottnitz et al., 2015) is still open; nonetheless, the active engagement of academic staff has been indicated as a starting point to drive transformative changes in curriculum innovation toward SD (Barth and Rieckmann, 2012). Increasing their interest and improving their competencies is indeed vital to engage faculty in the process of SD integration. However, previous studies suggest that the understanding and knowledge of SD remains a major challenge in this regard (Filho, 2011; Jones et al., 2008). The different understandings and the interdisciplinary nature of the terms involved have been described as blocking academics' engagement in education for SD (Cebrián et al., 2015; Sammalisto et al., 2015). An unquestioned issue is therefore to increase the awareness and knowledge of SD among university educators.

In the last decades, diverse educational initiatives have been promoted through a variety of initiatives addressed to different profiles of learner (Casey and Asamoah, 2016; de Wit and van der 
Werf, 1997; Wehrmeyer and Chenoweth, 2006), with the aim to increase the awareness and penetration of SD issues in different segments of the population. In the framework of the DESD, the Bonn declaration recognise the essential role of continued education to achieve sustainable lifestyles based on principles such as "economic and social justice, food security, ecological integrity, sustainable livelihoods, $[. .$.$] respect for all life forms, social cohe-$ sion, democracy and collective action" (UNESCO, 2009). The rapid obsolescence of knowledge in many fields and professions, the complexity of the debate on SD, as well as the continuous rise of new societal and environmental issues over time, makes it essential to address potential training gaps related to daily-life activities and work (Milana et al., 2016; Wehrmeyer and Chenoweth, 2006). As a consequence, continued education/professional development is critical to promote an aware and sustainable citizenship and, through specific programmes targeted to academics, can play a critical role in contributing to the integration of SD in universities.

Despite the increasing need to improve the capabilities of academic staff, to support the integration of SD at a curricula level (Ceulemans and De Prins, 2010; Verhulst and Van Doorsselaer, 2015), literature shows limited research on staff development programmes on SD, particularly in the field of engineering (Holmberg et al., 2008; Lozano and Lozano, 2014; Lozano García et al., 2008; Pérez-Foguet et al., 2005; Svanström et al., 2012).

The advances in technology have been increasingly facilitating the spread of web-based learning approaches (LeNoue et al., 2011; Wang et al., 2014), fostering different initiatives focused specifically on the promotion of SD at university level (Azeiteiro et al., 2014). Due to its flexibility and potential for customisation of the learning approaches of participants (Cornelius et al., 2011), and their potential to actively support constructivist approaches (Barth and Burandt, 2013; Dlouhá and Burandt, 2015), web-based initiatives on SD can have a clear attraction in continuing education and could contribute to maximising the participation to such initiatives. Despite successful examples of online courses addressed to academics on SD (Barth and Rieckmann, 2012; Boni and Pérez Foguet, 2006; Luppi, 2011), and other scientific fields (Psillos, 2017; Riviou and Sotiriou, 2017) the impact of e-learning approaches on SD addressed to academics remains understudied.

Given the increased interest in the role of web-based learning approaches to enhance the penetration of SD principles among academics and, specifically, the potential of these delivery methods to improve the competencies of engineering faculty in SHD, this study examines the following research question: in the framework of a continuing professional development initiative for engineering faculty, does participation in online SHD training result in academics acquiring relevant and useful knowledge for their teaching activities?

This research seeks to answer this question through the analysis of the learning process of a group of academics involved in online training courses implemented in the framework of the European initiative Global Dimension in Engineering Education (GDEE, 2015a). In terms of methods, the study comprised of both quantitative and qualitative indicators including data provided by i) a virtual learning platform (VLP) (enrolments, completion rate, grading, degree of participation and implication of participants), and ii) a survey addressed to courses participants assessing the perceived relevance and usefulness of online courses. The paper is organized as follows. Section 2 describes the characteristics of adult learning, focusing on the potential of digitally mediated learning environments. Section 3 focuses on the integration of SD into engineering curriculum, describing relevant staff development experiences. Section 4 reports the overall strategy and implementation of the GDEE initiative. Section 5 introduces the research methods. Results are presented in Section 6. Discussion and main conclusions follow in the last sections.

\section{Building an approach to continuing professional development for academics through digitally mediated learning environments}

This paper focusses on continued professional development for engineering academics; however lessons can be learned from other adult education literature. Adult education can generally be defined as the practice of teaching and educating adults, usually after compulsory education (Jarvis, 1996). In the last decades, the concept of 'lifelong learning' has been increasingly framing policy and practice towards adult education (Crowther and Sutherland, 2007; Grace, 2005). A distinctive feature of lifelong learning, in its initial idea, was related to a strategy shaping educational policies throughout the whole people's life, integrating a perspective of inclusion and emancipation, aimed at empowering individuals and communities for the promotion of social justice and democratic change (Delors, 1996; Faure et al., 1972; Gelpi, 1979). This humanistic perspective has been recently reasserted by UNESCO (2015). Nonetheless, currently there is no shared agreement on its usage. Critical views highlight that the current orientation of lifelong learning is increasingly focusing on individualist and instrumentalist directions (Blewitt, 2013; Grace, 2005; Grace and Rocco, 2009), following approaches aimed at maximising the function of education for promoting economic growth and competitiveness (Casey and Asamoah, 2016; Holford, 2016). Reporting different interpretation of lifelong learning, Edwards and Usher (2008, p. 59) emphasise a general agreement with the argument that 'lifelong learning is providing a strategy through which post-school education and training, including the education of adults, and potentially all education, is being and is likely to continue to be reshaped'.

Knowles et al. (2005), in a milestone work on adult learning, highlight specific characteristics that make the learning process of adults distinctively different. First of all adult learning is selfdirected, in the sense that adults take responsibility over the personal process of learning, being able to identify and define their learning needs as well specific learning strategies. Secondly, adults have a problem-centred approach to learning, perceiving meaning for issues that are relevant and immediately useful in their personal lives and/or in the work environment. Thirdly, adult approximation to learning is selective, in the sense that they are not inclined to learn issues that are not interested in. Finally, adult learning is based on previous knowledge and experience, as they draw upon their own resources in the learning process. This implies important considerations that must be taken into account for the effectiveness of adult learning process. The responsibility that adults are willing to take for their learning is strongly related to their learning motivation (Wlodkowski, 2003). Specifically, adults take responsibility on their own learning if they feel they have control over it, having the possibility of selecting what is really significant for them to learn, and possibly being involved in the planning of their own education process (Caffarella and O'Donnell, 1987; Merriam et al., 2007). Furthermore, adults bring into their learning process a wide range of personal resources including; previous experience, an established system of values, beliefs and preconceptions framing their thinking (Jarvis, 2004); as well as "predefined ideas for what they need to learn" (Beavers, 2009).

Given these characteristics, diverse learning strategies, predominantly based on a constructivist approach, especially tailored to adults, have been emphasised as specifically effective (Jarvis, 1996; Rubenson, 2016). Constructivism is based upon the notion that individuals constantly build new understanding as a result of the interaction between previous knowledge and the knowledge acquired through new experiences (Phillips, 2000). A social 
approach of constructivism has been traditionally promoted in adults' education, emphasising that individuals' representations and understanding of their self and the external world are influenced by political and social factors, such as the economy, power, religion, etc. (Richardson, 2003). Constructivist pedagogy emphasises the importance of the learning context for optimising learners' approach and motivation (Richardson, 2009). Specifically, knowledge is view as constructed by learners through social interaction with others (Huang, 2002), consequently, pedagogical approaches aim at actively engaging learners in open and interactive learning environments (Phillips, 2000).

Among the different learning strategies focused on adult learning, it is worth highlighting the following:

Self-directed Learning: it assumes that adults are responsible for their own learning and take initiative in defining autonomously their learning needs and goals (Brockett and Hiemstra, 1991). Accordingly, the teaching strategy aims at fostering learning processes in which learners develop their own knowledge independently, providing them with the ability to actively make choices on different aspects of their learning process (Caffarella and O'Donnell, 1987). Self-directed learning, opposed to mere knowledge transfer, dramatically improves the success of the learning experience.

Collaborative Learning: it appreciates that adult learning comprises both an individual and a social dimension. It aims at creating interactive learning environments where learners engage in common tasks allowing them working together to create common understanding, meaning, and solutions as a result of a collaborative learning process (Dillenbourg, 1999). It is specifically effective in adult learning since the possibility of sharing personal experiences and connections contributes in fostering group engagement and promoting a supportive learning environment (Scherling, 2011).

Active Learning: it acknowledges that the learning process improves when learners engage actively, applying their acquired knowledge, rather than absorb it passively (Bonwell and Eison, 1991). Therefore, it aims at providing learners the opportunity to put in practice the notions learnt acting on a specific piece of content, either individually or in groups. Practical application consists of short writing, peer activities, simulations, group discussions, problem solving activities, etc. Specifically, problembased learning (or problem-oriented learning) is an activity considered especially effective in adult learning (Karge et al., 2011). Learners are provided with complex real-world problems and some guidelines on how to solve them. The group analysis of the different approaches and perspectives applied to solve these authentic situations enrich the learning process of participants.

Transformative Learning: it defends that through relevant learning processes, adults can re-evaluate and reframe previous assumptions, patterns and ideas of self and others, and the society, often uncritically accepted (Kitchenham, 2008; Mezirow, 2000). Accordingly, this strategy aims at fostering learners to critically question their frames of reference and mental habits - including perspectives, forms of reasoning, beliefs etc. - through different activities such as discussion, critical reflection, alternate perspectives, role plays etc. (Cranton and King, 2003).

Experiential Learning: it acknowledges that different styles of learning might be involved in the processes associated with making sense with concrete experiences (Fry and Kolb, 1979). Specifically, Kolb (1984) learning theory sets a four-stage learning/training cycle that ideally applies to all learners, identifying four learning styles associating a specific learning preference: i) assimilators - sound logical theories; ii) convergers - practical applications of concepts and theories; iii) accommodators - practical experiences; and iv) divergers - observation and collection of information. Corresponding strategies take into account different possible adults' preference in order to maximise their learning experience (Honey and
Mumford, 1992).

Education programmes targeted at adults usually combine the highlighted strategies to improve the effectiveness of the learning experience (Lawler and King, 2000). Literature focusing specifically on the professional development of educators emphasise that the combination of these strategies, adapted according to the characteristics of the group of learners, provides a significant learning experience for participants (Beavers, 2009; Gregson and Sturko, 2007; Lawler and King, 2000). Contextually, a reiterated suggestion recommends avoiding traditional approaches based on simple transmission of information, ignoring experience and professional knowledge of participants (Brockett and Hiemstra, 1991; Wlodkowski, 2003). Instead, adult educators should be perceived as facilitators of significant learning experiences, specifically: i) encouraging the active participation in all the process, through learner-centred pedagogies aimed at building learning on personal experiences; ii) creating a climate of mutual respect where experiential and collaborative learning can easily take place; iii) providing learning immediately applicable to professional context; and iv) paying specific attention to internal motivation of learners (Wlodkowski, 2003).

\subsection{Digitally mediated learning}

The spread of new technologies in the world of education has created new opportunities, especially for the professional development of adults. Along with the clear advantages in term of flexibility, giving learners the possibility to participate at their own convenience and according to their own style and pace of learning, new technologies currently offer dynamic learning environments with a great potential to enhance the active engagement of participants in the whole learning process (LeNoue et al., 2011). The current range of distance learning include different typologies of courses, including fully online courses, courses offered through blended learning - combining face-to-face approaches with online delivery - and 'technology enhanced options', mainly based on a face-to-face approach while integrating elements of digitallymediated learning (Palloff and Pratt, 2007). These delivery approaches currently integrate a growing number of technologies (including wikis, virtual worlds, online communities, internet forums, RSS feeds, peer-to-peer media sharing technologies, blogging, gaming, and many more) that, applied to the educational environment, contribute to a dramatic improvement of the learning customisation and flexibility to "accommodate individual learner characteristics, preferences, motivations and goals" (Bae et al., 2015; Cornelius et al., 2011). Furthermore, constructivism principles can be effectively applied in distance learning applying proper instructional guidelines (Dlouhá and Burandt, 2015; Huang, 2002; Richardson, 2009).

As rightly emphasised by Barth and Burandt (2013), e-learning, compared to the traditional face-to-face learning approaches, does not intrinsically provide better or more efficient learning processes. Nonetheless, it presents a clear potential for a socio-constructivist approach of adult learning, framing the learning process encouraging autonomous and independent learning as well as increasing the opportunities for collaboration and the construction of new knowledge. As an example, open learning environments are learning design frameworks aimed at maximising users' control over their own learning process, supporting personal sense making of learners providing, through enriched technology tools and resources, concrete experiences involving authentic problems (Hannafin et al., 2004). Such environments, based on authentic learning and promoting divergent thinking and multiple perspective, are especially suitable for competence development of learners and are designed following some of the strategies 
described above: self-directed learning, collaborative learning and problem-oriented learning (Barth and Burandt, 2013). Accordingly, advanced online technologies along with sound instructional strategies can offer adult learners effective educational approaches maximising constructivist pedagogies (Huang, 2002; Psillos and Paraskevas, 2017).

\section{Promoting the integration of sustainable human development into engineering curriculum}

The main goal of SD professional development programmes for academics is to promote faculty competence development in order to change their teaching practice, integrating SD principles in regular curricular activities. The literature focusing specifically on SD lifelong learning addressed to academic staff highlights that professional development facilitates their learning and teaching capabilities, as well as promoting personal reflection on possible implementation of SD principles into teaching (Barth and Rieckmann, 2012; Lozano García et al., 2008). Furthermore, for an effective integration of SD principles into academic activities, specific training processes such as the 'educating the educators' are reported as a relevant aspect fostering a clear understanding of the principles of SD (Lozano, 2006).

The integration of SD in curricular activities can be promoted in different ways. Lozano and Lozano (2014) indicate four main approaches that have been used in combination or independently: i) some coverage of some environmental issues and material in an existing module or course; ii) a specific SD course; iii) SD intertwined as a concept in regular disciplinary courses, matching the nature of each specific course; and iv) SD as a possibility of specialization within the framework of each faculty. These options have been differentiated in vertical or horizontal integration (Watson et al., 2013). The former approach calls for including a specific course to the curriculum, namely the option ii, while the latter comprises different range of integration, specifically options $i$, iii and iv. Vertical integration might not provide students with adequate opportunities to incorporate SD into their professional practice (Lourdel et al., 2005; Rose et al., 2015); instead, intertwining SD as a concept within regular courses has been described as the most favourable approach for integrating SD (Lozano and Lozano, 2014). These different approaches can be combined depending on the university strategy.

The integration of SD into engineering curricula has been conducted according to different approaches, primarily through the implementation of SD individual courses (Boks and Diehl, 2006: Davidson et al., 2010; Kamp, 2006), as well as through whole curriculum reform (Fenner et al., 2005; Lozano and Lozano, 2014; Rose et al., 2015; von Blottnitz et al., 2015). The educational strategy of curriculum reform has been focused either by integrating changes in content (Lozano and Lozano, 2014; Watson et al., 2013), emphasising a new framing of learning outcomes (Biswas, 2012) or focusing on the articulation of competencies (Wiek et al., 2011). Nonetheless, scholars indicate that curriculum changes have mostly been framed in terms of changes of content with little consideration of desired learning outcomes (Rose et al., 2015). Furthermore, literature includes limited examples of testing assessing changes in learning outcomes as a result of curriculum change. The assessment measurement has been based on different approaches, including: student satisfaction (Biswas, 2012), conceptual maps (Segalàs et al., 2010) and changes in students' attitude (Schneiderman and Freihoefer, 2012). Limited insight in the literature is available to understand these processes of integration of SD in universities' curricula (Desha et al., 2009; Velazquez et al., 2005). However, academic staff have been recognized for being the prime contributor for curriculum reform (Fenner et al., 2005; Holmberg et al., 2008; Lozano, 2006) and a catalyst for curriculum change towards SD (Barth and Rieckmann, 2012).

The literature focused on engineering education for SD reports different experiences of staff professional development, aimed at fostering the integration of SD principles into engineering curricula. Boni et al. (2004) and Boni and Pérez Foguet (2006) presented blended-learning initiatives addressed to academics, driven jointly by Universities and international Non-Governmental Organisations (NGO), such as Engineering Without Borders and OXFAM Spain. Furthermore, Pérez-Foguet et al., 2005 proposed the use of fieldbased case studies as supporting teaching materials aimed at integrating SD in engineering courses. Lozano García et al. (2008) proposed an 'educate the educators' course, based at the Tecnológico de Monterrey (Mexico). The course was structured combining traditional training activities, such as lectures, readings, class role play activities, etc., with a workshop-format aimed at helping the educators incorporate SD issues within their own courses. Pérez Foguet and Lobera (2008) summarize theoretical background and illustrate practical applications materials developed by lecturers in the context of a course addressed to academics focused on the crosscutting integration of competencies related to 'Sustainability and Social Commitment' in technical courses. Ceulemans and De Prins (2010) developed an 'educate the educators' self-instructional manual, focusing on how to integrate SD into the curriculum of 'commercial engineers', at the HogeschoolUniversiteit Brussels. Barth and Rieckmann (2012) analysed an academic staff development programme implemented at the Universidad Técnica del Norte (Ecuador), set out as a blended-learning course. The approach combined a moodle-based e-learning environment with five face-to-face seminars. A particularly successful approach, applied in Chalmers University of Technology (Holmberg et al., 2012; Svanström et al., 2012), combines individual interaction, such as individual coaching discussions, with specific workshops addressed to different engineering programmes (Holmberg et al., 2008). This approach, as reported by Mulder et al. (2012, p.213) reversed the "teach the teacher approach", specifically because academics are engaged in the learning process by "proposing contributions to SD' from their own expertise, instead of being trained. More recently, Lozano and Lozano (2014) presented the development of a new Bachelor degree in 'Engineering for Sustainable Development' - based at the Tecnológico de Monterrey - incorporating SD throughout all curricula. Faculty engagement and empowerment was fostered through a course designed to educate the educators.

\section{The GDEE approach to continuing professional development for academics}

\subsection{The project strategy}

The GDEE initiative was launched in 2012 with the aim of mainstreaming SHD in engineering education and ultimately promoting the development of key capabilities and skills of academics and students studying engineering degrees in the HE system across the EU. To do this, the initiative sought to i) improve competences of faculty of engineering universities to effectively integrate SHD as a crosscutting issue in teaching activities, and to ii) increase engagement of both faculty and students in initiatives related to SHD. The consortium of partners comprised of five European universities (Polytechnic Universities of Catalonia, Madrid and Valencia - Spain; Loughborough University - UK; and University of Trento - Italy) and four international non-governmental organisations (NGOs) (Engineering Without Borders - UK; Practical Action - UK, ONGAWA - Spain; and the Training Centre for International Cooperation - Italy). 
The university-NGO partnership was aimed at reinforcing the cooperation between civil society and academia, which has been recognized as a key driver to promote SHD in formal teaching programmes at all levels of HE (Pérez-Foguet, 2008; Zolezzi et al., 2013). These partnerships have been typically promoted in the field of international development (Boni et al., 2015), and the majority of them focus on mobility programs for both faculty and students to promote real-life experiences within NGO programmes in developing contexts. These approaches, well-grounded on sound partnerships at the national level, are rarely implemented at a regional - e.g. European - level. The GDEE made a remarkable effort to overcome this country-based perspective by promoting a European perspective on international development issues.

The methodological approach driving this initiative was founded on relevant experiences of capacity building on SD addressed to engineering faculty cited in the previous section, specifically, following Fenner et al. (2005), Boni and Pérez-Foguet (2006) and Barth and Rieckmann (2012). The initiative, focused on a socioconstructivist approach, specifically aimed at providing academics with appropriate information in order to facilitate a deeper personal reflection and understanding of SD concept and principles, but also to provide learning environments and practical tools aimed at fostering discussion and collaboration among other learners and tutors, and encouraging hands-on applications in their teaching activities.

Within this framework GDEE courses and activities were designed through a transdisciplinary process involving representatives of all institutional partners, comprising academics and practitioners. In addition, a set of case studies were jointly developed by academics and practitioners as a practical resource to provide academics with teaching materials, based on real cooperation projects, to be used with students in the classroom. The courses were structured to enhance the reflection and understanding of essential concepts and interconnected elements of SHD (see the details in Appendix B), as well as to actively involve academics in a collaborative learning context designed to be open and interactive where new knowledge can be generated through discussions and collaboration among the academics involved. The Global Dimension (GD) concept was emphasised to increase awareness among engineering students about global citizenship, thus promoting a sense of global social responsibility (Bourn, 2014). In particular, the courses sought to increase understanding of sustainability, international development and human rights, along with equality issues and environmental challenges. The ultimate aim was to educate engineering students from a global perspective, increasing their awareness about SHD challenges and empowering them to contribute from their professional career to poverty reduction, human rights issues, and conflict resolution. This does not stand alone within engineering education, as linkages with other development-related agendas are remarkable, such as globalisation, sustainability, humanitarian issues and ethics (Trimingham et al., 2016).

The project included different complementary activities aimed at up-skilling, motivating and engaging academics in SD issues. Specifically, this research, focuses on the professional development of engineering faculty through a series of on-line training courses using specific training materials addressed to academics comprising elaboration of training materials for academics, as open educational resources (OER), which was complemented with the joint elaboration (practitioners and academics) of contextual case studies (teaching materials), as OER.

\subsection{Competencies}

The list of competencies to be acquired by teaching staff after courses' completion was defined through a collaborative process between all project partners. Specifically, two 'focus group discussions', each of the duration of approximately one hour, were performed at the beginning of the project, with fifteen people participating in each session, representing all project partners. One of the authors adopted a facilitator role. Following Morgan (1988) proposal, sessions were recorded and transcribed verbatim, identifying the contributions of each individual. Then, individual contributions were grouped and classified as either 'university' or 'NGO' contribution. A rough thematic guideline for the sessions was proposed based on previous research on SD competencies (Segalàs et al., 2010; Svanström et al., 2008; Wiek et al., 2011). The results of this transdisciplinary collaborations were broadly reflected in competencies development (see Table 1), which were the reference point for the development of learning outcomes (Appendix B) and courses (Appendix A).

\subsection{Development of materials}

With the aim to support the practical implementation of each course, a set of training materials were been developed by selected European experts in this field. Nine separate publications, one for each course, were published and offered to learners (GDEE, 2014). Each publication corresponds to one course and includes five chapters, one chapter per course session. Alongside training materials, a set of contextual case studies were also developed as teaching materials (GDEE, 2015b), aimed at providing academic staff with specific materials to be used in the classroom. In total, 28 case studies based on real development projects from NGOs', project partners, and external organisations were selected according to their relevance. Each case study was jointly developed between an academic, who provided the academic background and designed the activities, and NGO practitioners, who provided the context-based information. Almost one hundred academics, from different European universities, and forty experts in the field of development (from NGOs, development training centres, and engineering organisations, among others) closely collaborated in developing training materials and case studies. All these materials were published and disseminated as OER.

\subsection{Courses' implementation}

In all, nine open source online courses were designed. Courses were divided into three thematic blocks (see Appendix A) to cover a range of potential needs and motivations of academic staff, as well as different degrees of interest in development issues. Courses were conducted either in English - when implemented in Italy and UK or partially in Spanish and English, in the case of Spain. A set of learning outcomes was defined for each course session (see the details in Appendix B). Finally, assessment tools aimed at evaluating the progress of participants were also developed.

Each course ran for 3 weeks beginning on March 2014, with one week of break between courses, in order to meet the project timeline. In total, courses were designed to take approximately $25 \mathrm{~h}$ to be completed, including readings, quiz assessment and 'academic activities', consisting in developing practical implementations of the notions learnt through the sessions as class activities. Activities were evaluated by course coordinators, and participants were given different levels of feedback, such as commentaries and suggestions aimed at further developing proposed ideas into teaching modules. Each course was divided into five sessions, each of which included one reading lecture and a set of on-line resources (videos, reports, articles). In parallel, online group discussions and forums were promoted through VLP or online collaborative tools, such as 'LinkedIN groups'. To complete a session, $2 \mathrm{~h}$ in the 
Table 1

GDEE Competencies, adapted from (CSCT, 2008; Segalàs et al., 2010; Svanström et al., 2008; Wiek et al., 2011).

\begin{tabular}{|c|c|}
\hline Competencies & Description \\
\hline Systemic Thinking & $\begin{array}{l}\text { Ability to recognise and analyse the complexity of development issues across different domains (society, environment, economy, etc.) and across } \\
\text { different scales (local to global). Ability to identify locally and globally relevant SHD issues and to connect the local and global aspects. Ability to } \\
\text { analyse and explain the role of technology and engineering in a globalized context connecting local and global aspects. }\end{array}$ \\
\hline Knowledge & Ability to acquire relevant knowledge about SHD challenges and issues. Ability to select educational goals for SHD, taking into account the prior \\
\hline Acquisition & $\begin{array}{l}\text { knowledge of students, and the diversity within the group of learners. Ability to find partners outside the school community and to co-operate with } \\
\text { organisations that promote SHD. }\end{array}$ \\
\hline Ethic and Values & $\begin{array}{l}\text { Ability to include and embed in teaching SD Ethic and values, principles and goals. Ability to encourage students to question their beliefs and } \\
\text { assumptions on SD values such as justice, solidarity, dignity, participation, etc. in order to clarify their thinking. Ability to work with students on } \\
\text { contradictory beliefs, assumptions and values as well as moral dilemmas, specifically about the role of technology and engineering in sustainable } \\
\text { development issues. }\end{array}$ \\
\hline Action & $\begin{array}{l}\text { Ability to introduce SHD as crosscutting issues in teaching (introductory courses). Ability to advice students involved in fieldwork or other extension } \\
\text { activities during BSc projects or MSc thesis, typically within a formalized International Cooperation Project (mid-level courses). Ability to design and } \\
\text { implement a subject in the field of SHD (advanced courses). }\end{array}$ \\
\hline Emotion & $\begin{array}{l}\text { Ability to motivate students towards Sustainable Development issues through Leadership and Empathy. Motivate and facilitate participative problem } \\
\text { solving and Teamwork. Build capacity to understand diversity across cultures, social groups, and communities. }\end{array}$ \\
\hline
\end{tabular}

classroom plus $3 \mathrm{~h}$ of personal study were required.

In terms of coordination, every course was overseen by an academic who took the responsibility for the scientific and academic content. Each partner country (Spain, Italy and UK) selected course coordinators with both expertise and knowledge about web-based teaching and tools. Participants also had the support of technicians of online virtual platforms. Overall, a team of more than 30 people, including academics and professionals, coordinated and supervised the courses. The number of faculty learners - more than 200 people enrolled in the courses - varied consistently among the different courses. As discussed in the following sections, this number mainly depended on participants' interests and also on the dissemination strategy by partner universities. The open source nature of the online materials also allowed interested academics to 'dip in' without completing the courses.

\subsection{National implementation strategies}

Courses have been separately implemented in the three European partner countries. The rationale behind this approach was to promote participation through more locally-oriented dissemination strategies, as well as to empower the different partners and foster course replication and further diffusion of teaching materials. Dissemination was carried out at both national and European level through different university networks.

The courses were implemented in the three partners' countries through distance learning, but with different implementation strategies, as shown in Table 2.

In Spain, all courses have been offered through on-line learning via a moodle-based learning platform at the Polytechnic University of Catalonia. It is worth highlighting that three of the five universities participating in the GDEE initiative were Spanish, consequently the diffusion of the training activities has been prolific. Academics and staff of the three Spanish universities have closely collaborated in the implementation of the courses. The UK adopted a different strategy. Since partner Engineering Without Borders UK has historically worked in English universities, training engineering students and educators on SHD, it was agreed that it would lead the implementation of UK courses, with the academic support of Loughborough University. Instead of a university-based virtual platform, courses were run using online tools provided by social networks aimed at managing courses' content, such as google training tools (google groups and google documents) as well as 'LinkedIN groups'. Furthermore, social networks were used for promoting groups' activities. Specifically, discussion groups were set up using LinkedIn groups, in order to enhance the social dimension of training activity, namely the possibility to easily 'invite' external experts to discussions and forums; as well as to 'connect' with courses partners and experts. In Italy courses were run using the virtual platform of the University of Trento. Unlike the other partners' countries, here a blended learning approach was adopted. Specifically, the first sessions of each course were offered face to face or, alternatively, via videoconference with all registered members. The beginning of each course purposely coincided with workshops and other events organized jointly by universities and NGOs, addressed to academics and student in the framework of the GDEE initiative. This aimed at improving the connection and collaboration between academics and NGOs, exploring common fields of work and facilitating networking among academics, practitioners and students. Alongside this approach, courses were promoted for whole thematic blocks, namely were mandatory registering to the three courses comprised in each block.

From an educational point of view, some differences should be highlighted regarding online and blended courses. Literature comparing online versus blended learning environments emphasise significant distinction in terms of greater effectiveness from blended learning, as well as higher satisfaction and emotional engagement of learners (Conrad and Donaldson, 2012; Dixson, 2015). Besides, other initiatives remarks that online learners, compared with blended, report the perception of more workload and less clear courses' instructions (Lim et al., 2007). This suggests important consideration regarding psychological state of learners that has to be taken into account in designing clear online instruction and in handling learners' questions and requests (Pundak et al., 2014); specifically ensuring, as reported by Swan et al. (2001): i) frequent and quality interaction with instructors; ii) dynamic

Table 2

GDEE national implementation strategies.

\begin{tabular}{|c|c|c|}
\hline Spain & Italy & UK \\
\hline - Online approach & - Blended approach & - Online approach \\
\hline - Registration to single courses & - Registration to a whole Block (3 courses) & - Registration to single courses \\
\hline - Virtual Learning Platform & - Virtual Learning Platform & - Social networks (google tools, LinkedIN groups) \\
\hline
\end{tabular}


Table 3

Indicators.

\begin{tabular}{|c|c|c|}
\hline Indicator & Data & Source \\
\hline \multicolumn{3}{|c|}{ Perceived relevance and quality of the training proposal } \\
\hline Interest in the training proposals & $\begin{array}{l}\text { Number of } \\
\text { enrollments }\end{array}$ & $\begin{array}{l}\text { VLP, Courses } \\
\text { Coordin. }\end{array}$ \\
\hline $\begin{array}{l}\text { Propensity to complete training } \\
\text { programmes }\end{array}$ & Completion rates & $\begin{array}{l}\text { Virtual Learning } \\
\text { Platform }\end{array}$ \\
\hline \multicolumn{3}{|l|}{ Learning acquisition of participants } \\
\hline Engagement in training activities & $\begin{array}{l}\% \text { of extra activities } \\
\text { completed }\end{array}$ & $\begin{array}{l}\text { Virtual Learning } \\
\text { Platform }\end{array}$ \\
\hline $\begin{array}{l}\text { Grading of participants that completed } \\
\text { one or more courses }\end{array}$ & Grading & $\begin{array}{l}\text { Virtual Learning } \\
\text { Platform }\end{array}$ \\
\hline $\begin{array}{l}\text { Students perception of the knowledge } \\
\text { acquired }\end{array}$ & Survey & Survey \\
\hline
\end{tabular}

discussions; and iii) a transparent interface and easy navigation. Research available is generally limited to student settings and it is difficult to generalise these findings for faculty learners. No literature has been found regarding differences between learning through university virtual platforms and online tools provided by Google and social networks. The main difference can be analysed in terms of preference to traditional learning environments, such as virtual platforms, versus new tools integrating social media.

\section{Methods}

This study was designed to assess the role of online training courses addressed to academics, implemented throughout the GDEE initiative, with specific focus on the acquired capacities and skills by the academic staff. The Online Student Engagement Scale (OSE), proposed by Dixson $(2015,2010)$ was taken as reference point to measure adult learners' engagement. The OSE combines objective behavioural validation, assessed through online information available from the course management system, with learners' self-perception of their engagement, assessed through a survey. The OSE measurement comprises four factors:

- Skills (staying up on readings, listening/reading carefully);

- Emotional (applying course material to their lives, desiring to learn the material);

- Participation/interaction (participating actively in discussion forums);

- Performance (getting a good grade, doing well on tests/quizzes).

Adapting Dixson (2015) methodological proposal, the methods employed in the analysis of the learning process of participants in GDEE online training courses included two complementary set of indicators, aimed at assessing the effectiveness of online courses, as shown in Table 3 and described in detail below.

\section{a. Perceived relevance and quality of the training proposal.}

The GDEE courses, as the majority of free online courses, had no requirement of completion, nor any kind of obligations for the academics registered. Therefore, it can be argued that the willingness of faculty to participate and to complete the courses relied mainly on their perceived relevance and quality of curricula and activities proposed. The assessment of the perceived relevance and quality of GDEE courses has been measured through two indicators:

- Interest in the training proposals: this quantitative indicator will be assessed through the number of enrolments in the different national training proposals.
Table 4

GDEE grading scheme.

\begin{tabular}{ll}
\hline Assessment & Grading \\
\hline 5 Quizzes (10 points maximum each) & Max. 50 points \\
2 Academic Activities (10 points maximum each) & Max. 20 points \\
1 Final multiple choice quiz (30 points maximum) & Max. 30 points \\
\hline
\end{tabular}

- Propensity to complete training programmes: this quantitative indicator will be assessed through courses completions rates.

The most successful strategy, namely the one that maximised the number of enrolments and completions, will be analysed through the following indicators.

\section{b. Learning acquisition of participants}

The Individual learning of participants on SHD-related issues was assessed through two complementary indicators:

- Engagement in training activities: this quantitative indicator will be assessed through the percentage of extra activities completed, namely activities potentially not required to formally complete a course.

- Grading of participants that completed one or more courses: this quantitative indicator will be assessed through the grading values of participants.

- Perception of the knowledge acquired: this quantitative and qualitative indicator was assessed through a survey addressed to participants at the end of each course.

Data collection has been performed using two main sources: i) data extracted from VLP (and provided from courses coordinators in the case of courses run in UK), and ii) a survey addressed to participants at the end of each course.

\subsection{Completion, assessment and grading of GDEE courses}

The number of enrolments, completion rates, grading and the assessment of activities' have been gathered from the virtual platforms used to impart online courses or directly provided by English partners who ran courses through social media. The completion rate is defined as the "percentage of enrolled participants who satisfied the courses criteria in order to earn a certificate". The evaluation criteria is presented in Table 4 and consisted of: i) five multiple-choice quizzes, at the end of each session, aimed at assessing the degree of understanding of SHD theoretical concepts and issues presented through courses 'materials; ii) two 'academic activities', namely practical implementations of the notions learnt through the sessions as class activities; and iii) a final multiple-choice assessment. To complete a course, a minimum of 70 points was required; therefore, participants could complete each course completing assessment quizzes (one for each session) and the final multiple-choice quiz. 'Academic activities' were the most demanding assignments and were conducted according to time availability and interests of trainees. Participation and contribution in the discussion forum were not graded individually. However, students were strongly encouraged to participate to discussions and course coordinators assessed the quality of discussions and group performance.

\subsection{Survey}

At the end of each course, participants were asked to answer a 
Table 5

Survey structure.

Individual perception of the impact of the training

Q1 Expectations and personal objectives

Likert scale

Q2 Knowledge and interest in SHD's crosscutting issues

Q3 Courses' usefulness to integrate SHD in teaching activities

Relevance and quality of courses' materials

Q4 Relevance of courses' materials for integrating SHD in Likert scale teaching act.

Q5 Overall quality of courses' materials

Q6 Usefulness of specific sessions

\section{Role of course coordinator}

Q7 Competence and knowledge of the topic

Q8 Promotion of participation, debate and exchanges of opinion

Q9 Details on the role of course coordinator

Suggested improvements

Q10 Missing topics

Q11 Potential improvements
Likert scale

Likert scale

Likert scale Open-ended question

Likert scale Likert scale

Open-ended question

Open-ended question Open-ended question

semi-structured survey aimed at deepening their perception of the usefulness of the training activity as well as the quality of the materials. Following the design and validation process for questionnaires reported by Larrán Jorge et al. (2013, p. 37), the data collection tool was designed and validated through a number of different steps. Firstly, an extensive literature review, specifically related to training and competence assessment (Segalàs et al., 2010, 2009; Wiek et al., 2011) and on learners' assessment and engagement in online courses (Conrad and Donaldson, 2012; Fink, 2013; Prinsloo and Slade, 2014), specifically focusing on the OSE (Dixson, 2015, 2010), have been performed. The survey was then validated by a panel of experts of the three Spanish partner universities. Finally, a second validation of the survey was conducted involving a group of faculty registered on the Spanish GDEE courses.

The survey comprised seven closed questions, employing a five point Likert scale from 'totally disagree' to 'totally agree', which were complemented with four open-ended questions to ask respondents to discuss their training experience on different academic issues. Table 5 shows the structure of the survey in detail. Contextually, an analysis of activities developed by participants to complete each course was conducted in order to obtain insights into the relevance of the programme in helping train faculty to change teaching routines, starting from respective fields of expertise.

\section{Results}

\subsection{Perceived relevance and quality of the training proposal}

\subsubsection{Overall analysis of nationals training proposals}

The GDEE courses ran from March 2014 to May 2015. Overall, roughly 220 people enrolled to one or more courses for a total of 885 enrolments; with a median average of 98 participants per course. Enrolled academics came from more than fifty European universities. The majority of participants (80\%) are linked to a university, while NGO training personnel represented the second largest group, with $13 \%$. The majority of participants from HEIs were academics or researchers (63\%), PhD students (29\%) and staff members (3\%). Females appear to be more interested in this initiative, representing the $58 \%$ of the total university participants.

As reported in Table 6, the number of enrolments is significantly

different among the three partners' countries. It is noted that, due to a very low number of enrolments, courses C8 and C9 in UK have been offered eventually through the Spanish online platform.

The distribution of enrolments in each of the three training centres is, respectively, $71 \%$ Spain, $13 \%$ UK, and 16\% Italy; and courses' completions follow, roughly, the same trend. Besides, the analysis of the composition of participants shows that, in the case of Spain and UK, academics make up the majority of participants, respectively with $65 \%$ and $77 \%$ over the total registered, while Italy courses attracted primarily $\mathrm{PhD}$ students, representing $53 \%$.

As reported in Table 5, completion rates of GDEE courses varied across different courses and thematic blocks. Overall, the highest rates of completions were registered during the introductory (A1, A2) and the mid-level blocks. The trend indicates a decrease within the first thematic block, then a slight increase for courses B4 and B5, then a clear decrease for the last thematic block. Overall the completion rates of GDEE courses can be considered very high when compared with other free online courses, such as Massive Open Online Courses (MOOCs), with completion rates of less than $10 \%$, with a median average of $6.5 \%$ (Jordan, 2014).

At national level, completion rates varied among the three national training implementations. In the case of Spain, the introductory block of courses presented the highest rates (respectively with $40 \%, 37,31 \%$ and $28,77 \%$ ); then rates decreased for the midlevel block, and then presented similar values for advanced block. In Italy and UK rates followed a different trend, courses B4 and B5 of the Mid-level Block - addressed to academics who want to advise students involved in field-work within an international cooperation project - presented the highest values. Then, for the other courses, rates presented a more uniform distribution. Given the limited time that academics have to devote to CPD programmes, and compared with other free online courses, it can be argued that there is a good propensity to complete the training courses. This can be related to a perceived high relevance and usefulness of curricula and proposed activities.

\subsection{Perceived quality/relevance of Spanish training courses}

As mentioned above, data shows that the implementation strategy in Spain, based on online training courses through a VLP, has maximised the number of enrolments and completions of the courses. As it appears to be the most successful of the three strategies, the analysis of the learning process of participants will focus on courses offered through Spanish platform.

Another indicator of perceived relevance and usefulness of training programmes relates to the level of engagement of academics in training programmes. It has been measured through the number of extra "academic activities" completed, i.e. activities that were not initially required to complete a course. These activities were specifically designed to help participants develop innovative ideas on how SHD concepts, learned through the theoretical sessions, could be embedded within their in teaching activities, taking the specific discipline and expertise of academics as starting point. They were aimed at gaining insight into relevant SHD issues, with a pedagogical approach that go beyond theoretical concepts, helping faculty questioning their teaching and explore new pedagogical approaches. Fig. 1 presents the percentage of participants that carried out these activities. With the exception of courses A2 and A3, more than $60 \%$ of participants completed at least one activity. Overall, the majority of participants completed 2 activities.

\subsection{Learning acquisition of participants}

Overall grading of participants that completed one or more courses helped to quantitatively assess the knowledge acquired by 
Table 6

Completion rates for online GDEE courses.

\begin{tabular}{|c|c|c|c|c|c|c|c|c|c|}
\hline \multirow[t]{2}{*}{ Country } & \multicolumn{3}{|c|}{ Introductory Block } & \multicolumn{3}{|c|}{ Mid-Level Block } & \multicolumn{3}{|c|}{ Advanced Block } \\
\hline & $\mathrm{A} 1$ & $\mathrm{~A} 2$ & A3 & B4 & B5 & B6 & $\mathrm{C7}$ & $\mathrm{C} 8$ & C9 \\
\hline \multicolumn{10}{|l|}{ SPAIN } \\
\hline Enrolments & 65 & 67 & 73 & 60 & 63 & 74 & 66 & 73 & 84 \\
\hline Completions (\%) & $26(40 \%)$ & $25(37 \%)$ & $21(29 \%)$ & $16(27 \%)$ & $13(21 \%)$ & $13(18 \%)$ & $11(17 \%)$ & $13(18 \%)$ & $15(18 \%)$ \\
\hline \multicolumn{10}{|l|}{ UK } \\
\hline Enrolments & 29 & 25 & 24 & 10 & 14 & 11 & 6 & & \\
\hline Completions (\%) & $6(21 \%)$ & $5(20 \%)$ & $5(21 \%)$ & $3(30 \%)$ & $7(50 \%)$ & $1(9 \%)$ & $2(33 \%)$ & & \\
\hline \multicolumn{10}{|l|}{ ITALY } \\
\hline Enrolments & 23 & 23 & 23 & 14 & 14 & 14 & 10 & 10 & 10 \\
\hline Completions (\%) & $9(39 \%)$ & $7(30 \%)$ & $3(13 \%)$ & $6(43 \%)$ & $7(50 \%)$ & $3(21 \%)$ & $3(30 \%)$ & $2(20 \%)$ & $2(20 \%)$ \\
\hline \multicolumn{10}{|l|}{ TOTAL } \\
\hline Enrolments & 117 & 115 & 120 & 84 & 91 & 99 & 82 & 83 & 94 \\
\hline Completions (\%) & $41(35 \%)$ & $37(32 \%)$ & $29(24 \%)$ & $25(30 \%)$ & $27(30 \%)$ & $17(17 \%)$ & $16(20 \%)$ & $15(18 \%)$ & $17(18 \%)$ \\
\hline
\end{tabular}

the trainees. Fig. 2 shows the detail of participants' grades for the nine courses. A minimum of 70 points was required to complete a course but it is noted that a very high percentage of completions obtained a higher score (80-100), and six over nine courses show that $45-50 \%$ of participants obtained the highest score $(90-100)$. This can be assumed as an overall indicator of increased knowledge and understanding of a specific set of outcomes linked to each course.

Quantitative performance data of the courses was complemented with individual perception of participants on: i) impact of the training; ii) relevance and quality of courses' materials and; iii) suggested improvements. Data was collected through surveys after courses completion, and aggregated in the analysis into the three thematic blocks for analysis giving an overall picture of participants' perception of the training impact. Figs. $3-5$ present the answers, aggregated for thematic block, of the following questions:

- Q2. Please rate you agreement to the following statement: My knowledge and interest in cross cutting issues (such as MDG, $\mathrm{HD}$, extreme poverty, climate change, etc.) has increased as a result of this course.

- Q3. Please rate you agreement to the following statement: Overall, this course is useful for integrating crosscutting issues in teaching activities.

- Q4. Please rate you agreement to the following statement: The course materials provided are relevant and effective for integrating crosscutting issues in teaching activities.

Within each thematic block, a very high percentage of participants agree or strongly agree that, as a result of taking a course, their knowledge and interest in SHD cross cutting issues has increased. Likewise, a very high percentage of participants agree or strongly agree that the courses were useful for integrating crosscutting issues in their teaching activities and materials were relevant and effective.

Open-ended questions highlighted general considerations and suggestions of improvement that are common for the three blocks. First of all, time availability stood out as the main barrier described by participants in order to engage with the GDEE training activities. On the one side, participants stressed the need for more time to deeply examine interesting topics and, on the other side, that courses' schedule was too densely packed with activities and tight deadlines. Extending training periods and deadlines may improve engagement and effectiveness of courses.

Discussion forums are perceived as important spaces of interchange and debate, with high levels of engagement, especially for the courses in block A. Various criticisms converge on the fact that participants' contribution is intermittent and, overall, a lack of more levels of reflection is explicitly claimed. Participants recommended encouraging participation to the forums through possibly grading the contribution to discussions.

Regarding the assessment of the courses some academics suggested exploring alternative assessment methods for future editions. Quizzes were perceived as the best method, however, they recognized that, given the type of course and the limited time available, is probably the most effective.

With regard to Block A, participants pointed opposed positions that can be described as distinct polarities. Some stressed the appropriateness of materials and proposed training topics (the sessions that explicitly link technology with SHD issues were

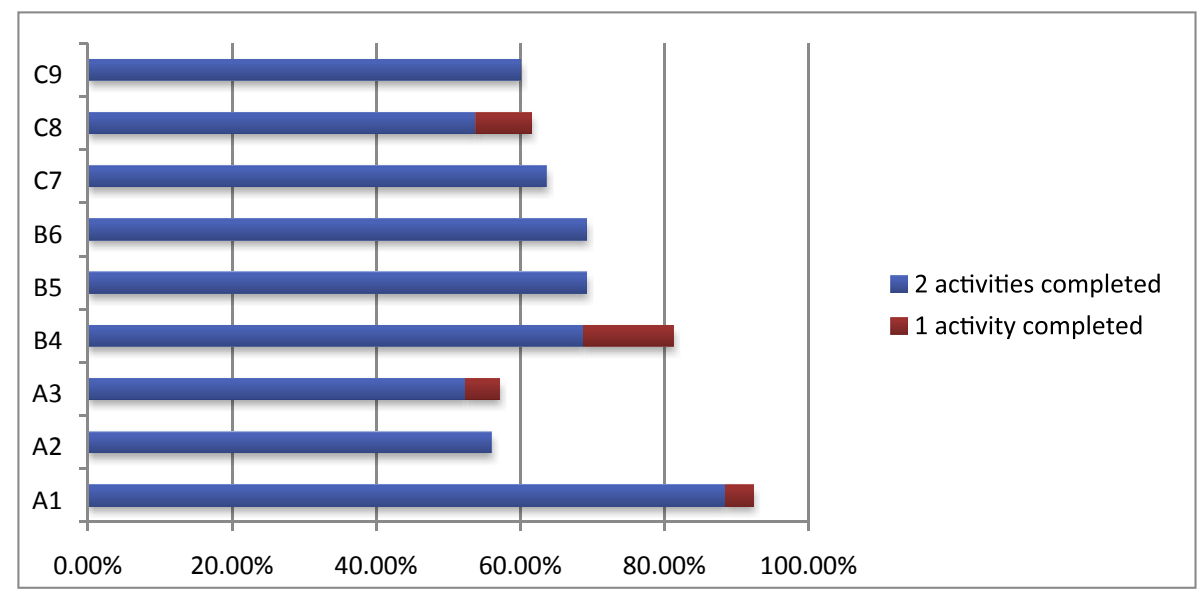

Fig. 1. Percentage of academic activities completed per course. 


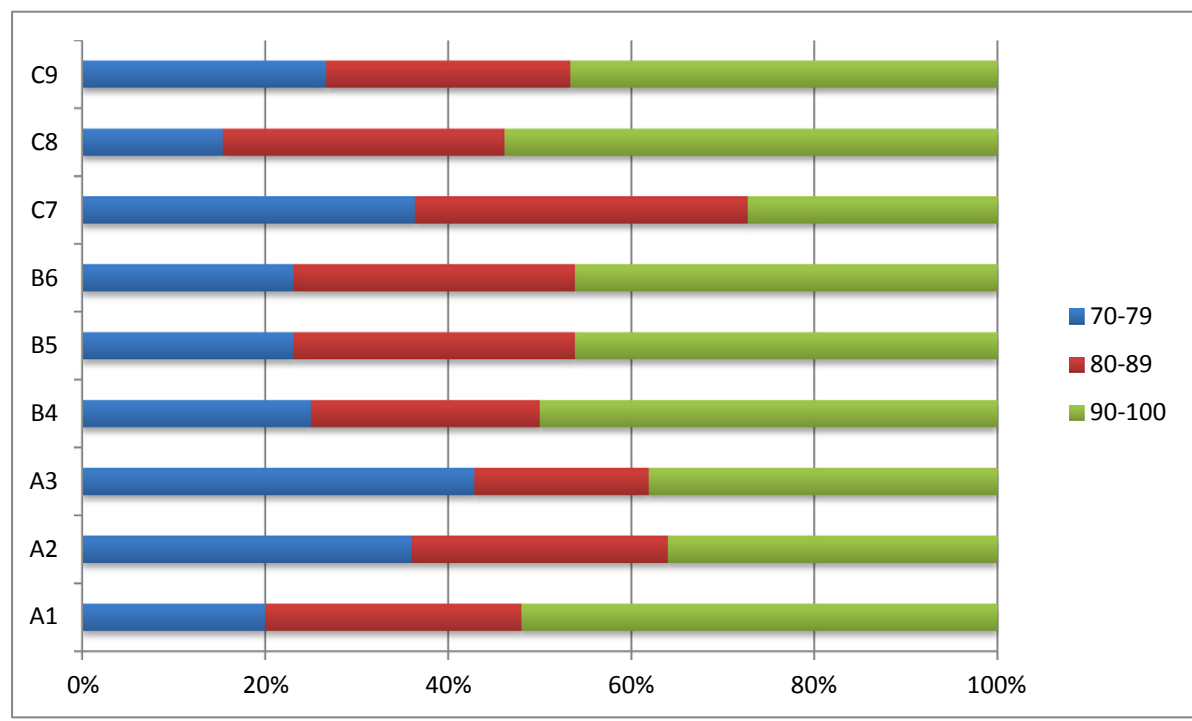

Fig. 2. Grading of Spanish completions.

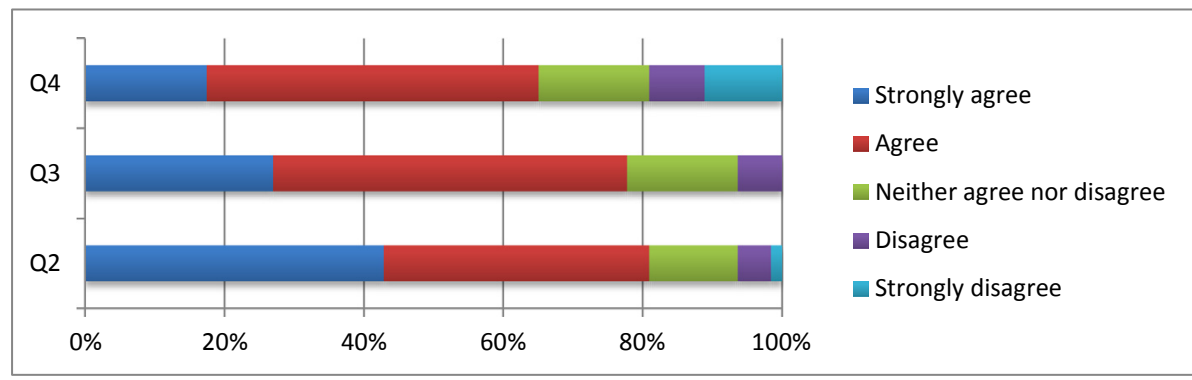

Fig. 3. Block A, responses to questions Q2, Q3, Q4.

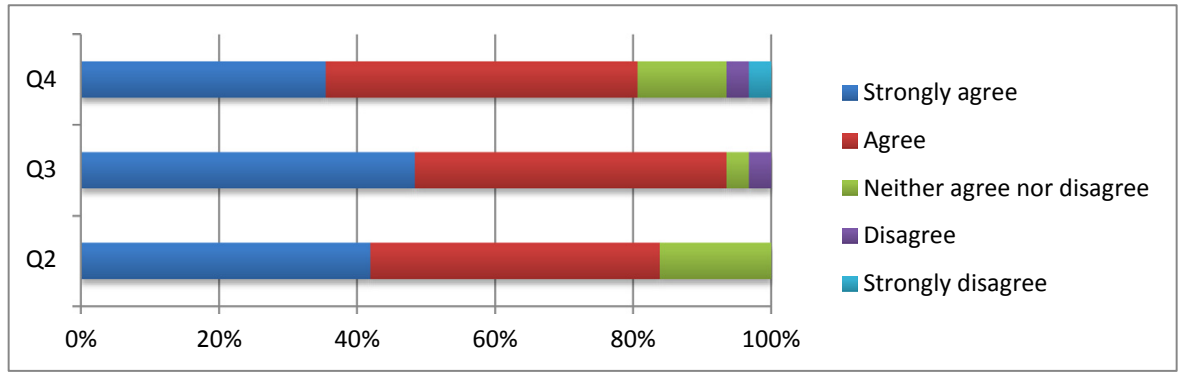

Fig. 4. Block B, responses to questions Q2, Q3, Q4.

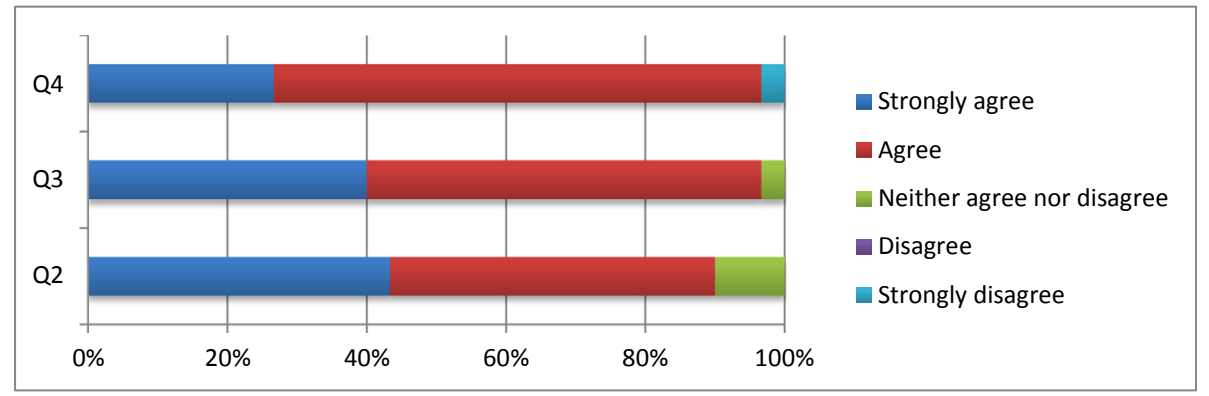

Fig. 5. Block C, responses to questions Q2, Q3, Q4. 
particularly appreciated by a large number of participants), while others underlined an excessive neutrality of courses' materials. In fact, several improvement suggestions asked for a more critical perspective on international development issues and the need of a more explicit questioning of traditional science and technology. A participant explicitly stated that he perceived courses approach too 'paternalistic and ethnocentric'. Others pointed out that materials 'avoid talking openly about politics' and that approximation was in general too politically correct. Also gender issues have been perceived, by few participants, not adequately integrated in the materials (inclusive language, examples, etc.).

Participants of the second block share the same general suggestions cited above for the three blocks. Furthermore, they highlight the need to integrate in courses' materials case studies on real international cooperation experiences. Especially suggested are videos and virtual seminars involving professors and NGO practitioners. Regarding the third block, more practical examples of teaching guides, evaluation schemes and activities have been claimed.

\section{Discussion}

The research discussed in this paper analysed the extent to which a continuing professional development approach addressed to engineering academics, based on a series of online courses aimed at raising awareness and promoting the integration of SHD in teaching activities, have positive effects on academics offering theoretical and practical tools through web-based learning.

The different implementation strategies, promoted at national level, have led to significant differences in the results among the three partners' countries, as can be appreciated from the data on enrolments and completion rates. Online courses fostered through the Spanish online learning platform represented roughly more than $70 \%$ of total enrolments and completions; while courses promoted in Italy and UK have not meet initial expectations.

Overall, the differences observed between the training proposals may highlight problems in the implementation strategy followed in the different countries. This can be related to different factors, interlinked and mutually reinforcing: i) different time availability for faculty professional development; ii) preference to traditional learning environments, such as university VLP; iii) academic relevance of national promoting institutions and iv) different degrees of permeability of the concepts promoted. Accordingly, the success of Spanish strategies, in terms of the number of participants, points out specific characteristics. Firstly, it was a more scalable training proposal, compared to the Italian offer, implemented with a blended learning approach. Secondly, courses were offered through a traditional online learning environment, such as VLP, possibly a more comfortable learning environment for academics, compared to social networks. Thirdly, the academic relevance of partners promoters; in fact, in Spain the three major polytechnic universities have locally promoted the GDEE courses, unlike Italy and UK where only one university has lead the promotion. Finally, the interest in concepts related to SHD, promoted through the heading of 'Global Dimension'; in Spain the GD represented a novelty while in the other countries other initiatives were promoted under this heading.

Completions rates of GDEE courses were particularly high compared to other e-learning proposals. Given the varied background and the broad range of motivation of participants, completion rate may be not the most robust indicator of the effectiveness of this training initiative among academics. Nevertheless, it can still be argued that GDEE completion rates, with values between $13 \%$ and $40 \%$, are higher than other free online courses (Jordan, 2014).
The analysis of the learning process of participants has been focused on Spain, the most successful of the three national implementations, highlighting a significant interest of academics in the training proposal. From one side, participants showed a high propensity to complete training programmes. On the other side, data emphasised a high degree of participation in training activities. Specifically, the majority of participants engaged in timeconsuming activities that were not required to formally complete a course but that were discipline specific. These data can be related to the degree of perceived relevance and usefulness of courses' curricula and materials, which has been confirmed and is reinforced by the other set of indicators, aimed at assessing the learning acquisition of the trainees. These results also confirm the fact that academics are willing to take responsibility of their own learning when the educational process and the contents proposed are perceived as useful and motivating, and when they are able to focus on what is really significant for them to learn (Knowles et al., 2005).

With regard to the knowledge acquired by participants, it may be reported that, as a result of taking a course, their knowledge and interest in SHD issues have increased. Besides, a very high percentage of participants indicated that courses were useful for integrating SHD issues in their teaching activities and that proposed materials were relevant and effective. This highlights important findings. First, that contents and methodologies employed, based on e-learning, have fostered successful knowledge acquisition and an effective learning experience, reinforcing previous initiatives (Barth and Rieckmann, 2012; Luppi, 2011); and confirming other studies reporting that e-learning approaches, compared with regular training options, can provide relevant learning (Psillos, 2017; Pundak et al., 2014) and similar knowledge retention (Girard et al., 2016). Second, that cooperation of academia with civil society, specifically from international development NGOs, can be beneficial for the professional development of faculty (Zolezzi et al., 2013). It can be argued that the development of curriculum and support materials addressed to faculty can be enriched through transdisciplinary collaborations including nonacademic entities. Specifically, the academic approach can be improved through field experiences offered by NGO.

In all courses, special attention has been devoted to fostering knowledge acquisition related to the complexity and interconnection of SHD issues, following Lozano García et al. (2008); particularly emphasising the links between different dimensions of sustainability, such as environmental issues, global and intergenerational justice, poverty and human well-being, sustainable use of resources, etc., as recommended by Boni and Pérez-Foguet (2008). Relevant content about global SHD principles and challenges, especially related to developing contexts, have been integrated in blocks A and B. Furthermore, concepts related to ethics and values (Holsapple et al., 2012) have been embedded in all nine courses, not only in materials but also in activities and forums.

Participants of courses of thematic blocks B and C acquired substantial knowledge about different learning and teaching methods as well as the ability to develop innovative practices for engaging with students. Advising students involved in field-work during BSc projects or MSc thesis (the specific topic of the block B), provided teaching staff with essential information on transdisciplinarity and its importance in finding practical solutions to SHD challenges in development contexts. Besides, they had the opportunity to deepen issues related to the cultural dimension of sustainability problem definition. Block C, addressed to academics that want to design a course relating technology and SHD from their own expertise, questioned the traditional discipline-oriented pedagogies developing SHD methodological competencies. Specifically, it developed appropriate teaching methodologies, interdisciplinary approaches and assessment strategies as well as practices 
aimed at fostering students' engagement.

SHD knowledge has been acquired combining theoretical and practical knowledge. Nevertheless, it is noted that the short duration and the full e-learning approach have not allowed the inclusion of, as part of the training, specific activities aimed at applying the concepts learnt in real teaching situations, ideally with the supervision of experts, as described by Barth and Rieckmann (2012) and Lozano García et al. (2008). In order to overcome this shortcoming, courses included practical activities providing learners the opportunity to apply their acquired knowledge on the integration of SHD concepts, developing proposals of class activities starting from the respective disciplines and expertise of academics involved (Holmberg et al., 2008; Svanström et al., 2012). Course coordinators gave detailed feedbacks on each activity submitted, including suggestions aimed at further developing proposed ideas into full teaching modules. Contextually, case studies were integrated as complementary tools, providing examples of class activities based on different disciplines and SD contexts. Practical activities were complemented by discussion forums specifically focused on teaching practices, where learners shared they experiences and discussed different opinions and approaches. Activities and forums, implemented through the VLP, aimed at facilitating respectively the integration of elements of active learning and the enhancement of the social dimension of the learning process. Learners' perception of online courses highlighted their usefulness to integrate SHD into teaching. Accordingly, it can be argue that they helped, at least, questioning the teaching routine and providing ideas to develop personal pathways to SHD integration.

Time availability of participants and tight schedules of courses were emphasised as the main obstacle to adequately engage with the GDEE courses. To meet the project timeline, courses had to be scheduled one after another with only one week of break among courses. This overload, in combination with demanding development training, might have affected participants' motivation to complete all course activities. In other words, one of the advantages of the web-based learning, namely the flexibility related to the learning pace of participants, has not been fully exploited. For further replication, it is strongly recommended employing flexible schedules, planning activities with an adequate timeframe allowing learners to deeply examine courses topics.

Other important recommendations focus on discussion forums. Specifically, it is suggested trying to devote adequate attention to make discussions effective, ensuring a constant engagement of participants and robust and rich discussions. Online discussions have a tremendous potential for the emotional engagement of learners (Conrad and Donaldson, 2012) and specific strategies, aimed at encouraging participation, should be integrated in a solid course strategy at the earliest stages, contextually to material development, as suggested by Bae et al. (2015). Furthermore, a lesson from this specific experience is that it is worth taking into account that political correctness (in course coordination, material development and discussion forums) and efforts aimed at assuring the neutrality of materials' content can be a double-edged sword, with the risk of compromising the engagement of a large part of participants. In this sense, it is worth stressing that several suggestions aimed at improving the courses materials called for a more explicit questioning of traditional science and technology and a more critical perspective on development issues.

The research presents some limitations, primarily inherent to the methodology employed. First of all, a highly quantitative approach was followed during the initiative. Complementing this data with more qualitative assessment, such as discussion groups or personal interviews, could have enriched and better described the learning experience of participants, including those who did not achieve course completions, providing important information to improve the replicability of the training initiative. Second, due to the fact that the specific profile of the target public analysed was university academics with similar backgrounds in engineering, results cannot be generalised to more generic adults' lifelong learning approaches.

\section{Conclusions}

This paper presents a study assessing the role of online training courses within continuing professional development strategies addressed to academics, in order to integrate SHD in engineering studies. It was built upon the implementation of a European initiative promoted by a transdisciplinary consortium of technical universities and non-governmental organisations. Two main conclusions are highlighted.

Firstly, online training approaches can be effective to promote academic staff development in SHD. Despite the limitations cited above, these approaches should be further explored. From one side, due to the limited amount of time available of academics to invest in continuing professional development, online training options can be well regarded by different profiles of academics. From the other side, the success of these training initiatives depends on specific conditions. Learning design framework should be aimed at maximising users' control over their own learning process, fostering opportunities for knowledge construction and personal sense making of learners. The workload and the pace of activities should be adequately planned in order to motivate participation and ensure continuity. Furthermore, the practical implementation of courses should take into account academic preference, specifically in terms of adequate/comfortable learning environments and expert trainers.

Secondly, an online, practical and collaborative learning environment facilitates successful learning and SHD knowledge acquisition. Beyond theoretical knowledge, academics are willing to engage in activities based on real-world problems, perceived as relevant and useful for their work environment. Furthermore, they are motivated to share personal experiences and debate on diverse perspectives and potential solutions in virtual spaces of discussion. Web-based environments can especially enhance these interactive situations, accommodating learners' preferences and goals.

In brief, online learning approaches and technologies can maximise the involvement of teaching staff and, in some cases, can be used as a way to overcome barriers related to universities' funding constraints.

In the light of these conclusions, the authors propose the following recommendations for the leaders of higher educational institutions, in their efforts aimed at holistically implement SHD into all of their institution's activities:

\begin{abstract}
- Acknowledge that continuing professional development of academics plays an essential role in the process of integration of SHD within institutional frameworks.

- Further explore the integration into university policy and strategies of digitally-mediated learning addressed to academics, in its different delivery approaches, as a way to promote professional development and the engagement of academics for SHD. - Carefully consider the demands of professional development of faculty, as well as specific characteristics, interests, motivation and goals towards SHD, in order to promote online learning experiences customised and centred on the academics.
\end{abstract}

\section{Acknowledgements}

The research was conducted in the framework of the European initiative Global Dimension in Engineering Education financed by: 
- European Commission, Non-State Actors and Local Authorities in Development, Raising public awareness of development issues and promoting development education in the European Union Reference: EuropeAid/131141/C/ACT/MULTI, Number of proposal: DCI-NSAED/2012/280-929.

- Barcelona City Council, Program: Barcelona Solidaria 2013. Grant number: 13ED0046.

Funding sources had no involvement in study design; in the collection, analysis and interpretation of data; in the writing of the report; and in the decision to submit the article for publication.

\section{Appendix A. GDEE course outline}

Course A.3: The global engineer in sustainable human development

1. Describe various theories of relationships between society and technology, and apply theories to develop new theories of sociotechnical relationships, which integrate a SHD perspective.

2. Compare different methodologies for the structuring and framing of problems which allow for a more holistic and multidisciplinary analysis of contemporary engineering practice.

3. Examine the function and culture of traditional business and management practices in the engineering sector in order to identify opportunities for the integration of SHD perspectives.

4. Explain the importance of engaging stakeholders and the public in engineering practice in order to develop a practice more in line with SHD principles.

\section{Block B. Supervising BS/MS thesis with fieldwork}

Course B.4: supervising engineering students introduce crosscutting issues in their activities; i.e., including a session related to SHD within, typically, a BSc course.

Course A.1: Making the case for a critical global engineer

Course A.2: Key elements for addressing the global dimension of engineering Course A.3: The Global Engineer in Sustainable Human Development

Block B - Supervising BS/MS Addressed to those academics who want to thesis with fieldwork: advice students involved in field-work or other extension activities during BSc projects or MSc thesis, typically within or close to a formalized International Cooperation Project.

Course B.4: Supervising Engineering Students Course B.5: Knowing the context and partners Course B.6: Knowing International Cooperation

Block C - Integrating GDE into Addressed to those academics (or teaching and research professionals) who want to design a course relating Technology and SHD, from their own technical expertise.

Course C.7: Integrating GDE into the academia Course C.8: Integrating GDE into Teaching: Theory and Practice

Course C.9: Integrating GDE into Research

\section{Appendix B. Intended learning outcomes of GDEE courses}

\section{Block $\boldsymbol{A}$. The global engineer}

Course A.1: making the case for a critical global engineer

1. Compare and contrast historical and contemporary views on engineering for development, applying relevant STS theories.

2. Evaluate a set of guidelines or standards governing the social responsibility of engineers in professional practice.

3. Identify relationships between technology and society, both in theory and practice.

Course A.2: Key elements for addressing the global dimension of engineering.

1. Analyse and examine critical debates on contemporary sustainable development practice, especially where these relate to engineering.

2. Analyse the complexity and interconnectedness of sustainable development issues across different domains (society, environment, economy, etc.)

3. Evaluate the relationship between ideas such as equality, citizenship and gender to development practice. Reflect on how these same ideas are represented in the engineering profession.
1. Apply knowledge of theories and dynamics of student supervision to improve the quality and effectiveness of their own practice.

2. Identify specific skills and competencies required for the supervision of students in a developing-country context.

3. Construct a set of guidelines informing the planning and reporting stages of a research project in a developing-country context, including planning stakeholder feedback and fieldwork preparation.

\section{Course B.5: knowing the context and partners}

1. Describe the relevant criteria to select partnerships in the International cooperation context.

2. Analyse concepts and principles to orient students developing a first broad understanding of the geographical, environmental, social, economical, political and cultural context of the countries where students are going to develop their thesis.

3. Illustrate the basic dynamics and principles governing interaction with and participation of stakeholders in the context of development projects, such as of "active listening" and conflict dynamics tools that can be useful in a specific case.

\section{Course B.6: knowing international cooperation}

1. Explain the importance of participatory approaches to research, and how these could be implemented to involve stakeholders at all phases of project cycle management.

2. Summarize and explain the basic principles of the logical framework approach applied to development research projects.

3. Develop an independent search of relevant grants and financial support for international cooperation projects, namely including support to engineering students' thesis.

\section{Block C. Integrating GDE into teaching and research}

Course C.7: integrating GDE into the academia

1. Describe the role of global dimension (GD) in engineering education, and summarize of how GD relates to other educational agendas (sustainability, humanitarian engineering, etc.) 
2. Identify and map the GD onto existing educational contexts and practices, including both content and the regulatory frameworks in which the contexts exist.

3. Compare practical understanding of different ways that the GD can manifest in the curriculum, as well as the advantages and disadvantages of each.

4. Identify the regulatory frameworks which operate on a European or in-country level.

5. Analyse the relevance of $M \& E$ to the development of new programming and prepare a preliminary $\mathrm{M} \& \mathrm{E}$ program for curricular interventions.

\section{Course C.8: integrating GDE into teaching: theory and practice}

1. Summarize the key learning theories related to GD, and how these relate to module structure development.

2. Define and document the skills and competencies within GD programming related to their discipline.

3. Construct a set of intended learning outcomes for GD-related programs.

4. Compare appropriate teaching methods and assessment strategies.

5. Identify methods for mapping the GD onto student motivations and prepare innovative practices for engaging with students.

\section{Course C.9: integrating GDE into research}

1. Identify how the implementation of GD-related programming can be informed through action and applied research.

2. Illustrate how to start adapting research programs to include more GD-related topics.

3. Compare the application of appropriate research methodology to conduct a research study in topics related to the global dimension in engineering education.

4. Identify sources of funding for GD-related topics.

5. Recognise the importance of collaboration to research stakeholders and open-source as a concept and practical tool.

\section{References}

Absell, C.D., 2015. The Lexicon of development: a quantitative history of the language of development studies. Iberoam. J. Dev. Stud. 4, 4-34.

Azapagic, A., Perdan, S., Shallcross, D., 2005. How much do engineering students know about sustainable development? The findings of an international survey and possible implications for the engineering curriculum. Eur. J. Eng. Educ. 30 1-19. http://dx.doi.org/10.1080/03043790512331313804.

Azeiteiro, M., Leal Filho, W., Caeiro, S. (Eds.), 2014. E-learning and Education for Sustainability. Peter Lang, Frankfurt am Main.

Bae, E., Prasad, P.W.C., Alsadoon, A., Bajaj, K., 2015. Framework to improve delivery methods in higher education through online learning. In: 2015 IEEE 7th International Conference on Engineering Education (ICEED). Institute of Electrical and Electronics Engineers Inc., pp. 130-134. http://dx.doi.org/10.1109/ ICEED.2015.7451506

Barth, M., Burandt, S., 2013. Adding the "e-" to learning for sustainable development: challenges and innovation. Sustainability 5, 2609-2622. http:/ dx.doi.org/10.3390/su5062609.

Barth, M., Rieckmann, M., 2012. Academic staff development as a catalyst for curriculum change towards education for sustainable development: an output perspective. J. Clean. Prod. 26, 28-36. http://dx.doi.org/10.1016 j.jclepro.2011.12.011.

Beavers, A., 2009. Teachers as learners: implications of adult education for professional development. J. Coll. Teach. Learn. 6, 25-30.

Biswas, W.K., 2012. The importance of industrial ecology in engineering education for sustainable development. Int. J. Sustain. High. Educ. 13, 119-132. http:/ dx.doi.org/10.1108/14676371211211818.

Blewitt, J., 2013. EfS;: contesting the market model of higher education. In: Sterling, S., Maxey, L., Luna, H. (Eds.), The Sustainable University: Progress and Prospects. Routledge, Abingdon (UK), pp. 51-70. http://dx.doi.org/10.4324/ 9780203101780.

Boks, C., Diehl, J.C., 2006. Integration of sustainability in regular courses: experiences in industrial design engineering. J. Clean. Prod. 14, 932-939. http:// dx.doi.org/10.1016/j.jclepro.2005.11.038.

Boni, A., Acebillo, M.B., Visscher, J.T., Hidalgo, S., Pérez Foguet, A., Carlos, D.C.N., 2004. Estrategias para el impulso de la educación para el desarrollo en la universidad. In: La experiencia del curso de Formación de Formadores universitarios ¿Educando en Tecnología para el Desarrollo Humano? Retrieved from: http://upcommons.upc.edu/handle/2117/26700.

Boni, A., Pérez-Foguet, A., 2008. Introducing development education in technical universities: successful experiences in Spain. Eur. J. Eng. Educ. 33, 343-354. http://dx.doi.org/10.1080/03043790802088723.

Boni, A., Pérez Foguet, A., 2006. Propuestas pedagógicas para la introducción de la educación para el desarrollo en las enseñanzas científico-técnicas. Intermón Oxfam. Retrieved from: http://upcommons.upcedu/handle/2117/24727.

Boni, A., Sastre, J.J., Calabuig, C., 2015. Educating engineers for the public good through international internships: evidence from a case study at Universitat Politècnica de València. Sci. Eng. Ethics. http://dx.doi.org/10.1007/s11948-0159728-z.

Bonwell, C.C., Eison, J.A., 1991. Active learning: creating excitement in the classroom. Learning 80819, 1-6 doi:ED340272.

Bourn, D., 2014. The global dimension to engineering education. In: PerezFoguet, A., Velo, E., Sierra-Castañer, M., Boni, A., Peris Blanes, J., Zolezzi, G., Trimingham, R. (Eds.), Making the Case for a Critical Global Engineer. Global Dimension in Engineering Education.

Brockett, R.G., Hiemstra, R., 1991. A conceptual framework for understanding selfdirection in adult learning. In: Adult Learning: Perspectives on Theory, Research, and Practice. Routledge, New York, p. 276.

Byrne, E.P., Desha, C.J., Fitzpatrick, J.J., "Charlie" Hargroves, K., 2013. Exploring sustainability themes in engineering accreditation and curricula. Int. J. Sustain. High. Educ. 14, 384-403. http://dx.doi.org/10.1108/IJSHE-01-2012-0003.

Caffarella, R.S., O’Donnell, J.M., 1987. Self-directed adult learning: a critical paradigm revisited. Adult Educ. Q. 37, 199-211. http://dx.doi.org/10.1177/ 0001848187037004002.

Casey, C., Asamoah, L., 2016. Education and sustainability: reinvigorating adult education's role in transformation, justice and development. Int. J. Lifelong Educ. 35, 590-606. http://dx.doi.org/10.1080/02601370.2016.1217281.

Cebrián, G., Grace, M., Humphris, D., 2015. Academic staff engagement in education for sustainable development. J. Clean. Prod. 106, 1-16. http://dx.doi.org/10.1016/ j.jclepro.2014.12.010

Ceulemans, K., De Prins, M., 2010. Teacher's manual and method for SD integration in curricula. J. Clean. Prod. 18, 645-651. http://dx.doi.org/10.1016/ j.jclepro.2009.09.014.

Clifford, K.L., Zaman, M.H., 2016. Engineering, global health, and inclusive innovation: focus on partnership, system strengthening, and local impact for SDGs. Glob. Health Action 9. http://dx.doi.org/10.3402/gha.v9.30175.

Conrad, R.M.M., Donaldson, J.A.A., 2012. Engaging the Online Learner: Activities and Resources for Creative Instruction. Wiley.

Cornelius, S., Gordon, C., Ackland, A., 2011. Towards flexible learning for adult learners in professional contexts: an activity-focused course design. Interact. Learn. Environ. 19, 381-393. http://dx.doi.org/10.1080/10494820903298258.

Cranton, P., King, K., 2003. Transformative learning as a professional goal. New Dir. Adult Contin. Educ. 98, 31-37.

Crowther, J., Sutherland, P., 2007. Lifelong Learning: Concepts and Contexts. Routledge, Abingdon (UK).

CSCT, 2008. Competencies for ESD (Education for Sustainable Development) Teachers (A framework to integrate ESD in the curri culum of teacher training institutes).

Davidson, C.I., Hendrickson, C.T., Matthews, H.S., Bridges, M.W., Allen, D.T., Murphy, C.F., Allenby, B.R., Crittenden, J.C., Austin, S., 2010. Preparing future engineers for challenges of the 21st century: sustainable engineering. J. Clean. Prod. 18, 698-701. http://dx.doi.org/10.1016/j.jclepro.2009.12.021.

de Wit, A.E., van der Werf, E., 1997. Professional training in environment and development: an example from the field of development co-operation. Int. J. Sustain. Dev. World Ecol. 4, 51. http://dx.doi.org/10.1080/13504509709469941.

Delors, J., 1996. Learning: the Treasure within (Paris).

Desha, C.J., Hargroves, K., Smith, M.H., 2009. Addressing the time lag dilemma in curriculum renewal towards engineering education for sustainable development. Int. J. Sustain. High. Educ. 10, 184-199. http://dx.doi.org/10.1108/ 14676370910949356.

Dillenbourg, P., 1999. What do you mean by collaborative learning. In: Collaborative-learning: Cognitive and Computational Approaches. Pergamon, Amsterdam, pp. $1-15$.

Dixson, M.D., 2015. Measuring student engagement in the online course: the online student engagement scale ( OSE. Online Learn. J. 19.

Dixson, M.D., 2010. Creating effective student engagement in online courses: what do students find engaging? J. Scholarsh. Teach. Learn. 10, 1-13.

Dlouhá, J., Burandt, S., 2015. Design and evaluation of learning processes in an international sustainability oriented study programme. in search of a new educational quality and assessment method. J. Clean. Prod. 247-258. http:// dx.doi.org/10.1016/j.jclepro.2014.09.096.

Edwards, R., Usher, R., 2008. A troubled space of possibilities Lifelong learning and the postmodern. In: Sutherland, P., Crowther, J. (Eds.), Lifelong Learning: Concepts and Contexts. Routledge, New York, p. 247.

Faure, E., Herrera, F., Kaddoura, A.R., Lopes, H., Petrovski, A.V., Rahnema, M. Champion Ward, F., 1972. Learning to Be: the World of Education Today and Tomorrow. UNESCO, Paris. 
Fenner, R.A., Ainger, C.M., Cruickshank, H.J., Guthrie, P.M., 2005. Embedding sustainable development at Cambridge University engineering department. Int. J. Sustain. High. Educ. 6, 229-241. http://dx.doi.org/10.1108/14676370510607205.

Ferrer-Balas, D., Lozano, R., Huisingh, D., Buckland, H., Ysern, P., Zilahy, G., 2010. Going beyond the rhetoric: system-wide changes in universities for sustainable societies. J. Clean. Prod. 18, 607-610. http://dx.doi.org/10.1016/ j.jclepro.2009.12.009.

Filho, W.L., 2011. About the role of universities and their contribution to sustainable development. High. Educ. Policy 24, 427-438. http://dx.doi.org/10.1057/ hep.2011.16.

Filho, W.L., 2000. Dealing with misconceptions on the concept of sustainability. Int. J. Sustain. High. Educ. 1, 9-19. http://dx.doi.org/10.1108/1467630010307066.

Fink, L.D., 2013. Creating Significant Learning Experiences, Revised and Updated (An Integrated approach to Designing college Courses).

Fry, R., Kolb, D., 1979. Experiential learning theory and learning experiences in liberal arts education. New Dir. Exp. Learn. 6, 79-92.

GDEE, 2015a. Global Dimension in Engineering Education [WWW Document]. http://gdee.eu/.

GDEE, 2015b. Case Studies for Developing Globally Responsible Engineers [WWW Document]. http://upcommons.upc.edu/handle/2117/88905.

GDEE, 2014 [WWW Document]. In: Global Dimension in Engineering Education. http://upcommons.upc.edu/handle/2117/26502.

Gelpi, E., 1979. A Future for Lifelong Education: Principles, Policies and Practices. Manchester University Press, Manchester.

Girard, J.P., Yerby, J., Floyd, K., 2016. Knowledge retention in capstone experiences: an analysis of online and face-to-face courses. Knowl. Manag. E-Learn. Int. J. 8.

Grace, A.P., 2005. Lifelong learning chic in the modern practice of adult education: historical and contemporary perspectives. J. Adult Contin. Educ. 11, 62-79. http://dx.doi.org/10.7227/JACE.11.1.6.

Grace, A.P., Rocco, T.S., 2009. Challenging the Professionalization of Adult Education: John Ohliger and Contradictions in Modern Practice. Jossey-Bass.

Gregson, J.A., Sturko, P.A., 2007. Teachers as adult learners: re-conceptualizing professional development. J. Adult Educ. 36, 1-18.

Hannafin, M.J., Kim, M.C., Kim, H., 2004. Reconciling research, theory, and practice in web-based teaching and learning: the case for grounded design. J. Comput. High. Educ. 15, 3-20. http://dx.doi.org/10.1007/BF02940927.

Holford, J., 2016. The misuses of sustainability: adult education, citizenship and the dead hand of neoliberalism. Int. Rev. Educ. 62, 541-561. http://dx.doi.org/ 10.1007/s11159-016-9591-4.

Holmberg, J., Lundqvist, U., Svanström, M., Arehag, M., 2012. The university and transformation towards sustainability: the strategy used at Chalmers University of Technology. Int. J. Sustain. High. Educ. 13, 219-231. http://dx.doi.org/10.1108/ 14676371211242544

Holmberg, J., Svanström, M., Peet, D.-J., Mulder, K., Ferrer-Balas, D., Segalàs, J., 2008. Embedding sustainability in higher education through interaction with lecturers: case studies from three European technical universities. Eur. J. Eng. Educ. 33, 271-282. http://dx.doi.org/10.1080/03043790802088491.

Holsapple, M.A., Carpenter, D.D.D., Sutkus, J.A., Finelli, C.J., Harding, T.S., 2012 Framing faculty and student discrepancies in engineering ethics education delivery. J. Eng. Educ. 101, 169-186. http://dx.doi.org/10.1002/j.21689830.2012.tb00047x.

Honey, P., Mumford, A., 1992. The Manual of Learning Styles.

Huang, H.-M., 2002. Toward constructivism for adult learners in online learning environments. Br. J. Educ. Technol. 33, 27-37. http://dx.doi.org/10.1111/14678535.00236.

Jarvis, P., 2004. Adult Education and Lifelong Learning: Theory and Practice, third ed. RoutledgeFalmer, London.

Jarvis, P., 1996. Adult and Continuing Education: Theory and Practice. Routledge.

Jones, P., Trier, C.J., Richards, J.P., 2008. Embedding Education for Sustainable Development in higher education: a case study examining common challenges and opportunities for undergraduate programmes. Int. J. Educ. Res. 47, 341-350. http://dx.doi.org/10.1016/j.ijer.2008.11.001.

Jordan, K., 2014. Initial trends in enrolment and completion of massive open online courses. Int. Rev. Res. Open Distrib. Learn. 15, 1.

Kamp, L., 2006. Engineering education in sustainable development at Delft University of technology. J. Clean. Prod. 14, 928-931. http://dx.doi.org/10.1016/ j.jclepro.2005.11.036.

Karatzoglou, B., 2013. An in-depth literature review of the evolving roles and contributions of universities to Education for Sustainable Development. J. Clean. Prod. 49, 44-53. http://dx.doi.org/10.1016/j.jclepro.2012.07.043.

Karge, B.D., Phillips, K.M., Jessee, T., McCabe, M., 2011. Effective strategies for engaging adult learners. J. Coll. Teach. Learn. 8, 53-56. http://dx.doi.org/ $10.19030 /$ tlc.v8i12.6621.

Kitchenham, A., 2008. The evolution of John Mezirow's transformative learning theory. J. Transform. Educ. 6, 104-123. http://dx.doi.org/10.1177/ 1541344608322678

Knowles, M., Holton, E., Swanson, R., 2005. The Adult Learner, sixth ed. Elsewier, London.

Kolb, D.A., 1984. Experiential Learning, Experience as the Source of Learning and Development.

Larrán Jorge, M., Herrera Madueño, J., Calzado Cejas, M.Y.M.Y., Andrades Peña, F.J., 2013. An approach to the implementation of sustainability practices in Spanish universities. J. Clean. Prod. 106, 34-44. http://dx.doi.org/10.1016/ j.jclepro.2014.07.035.

Lawler, P.A., King, K.P., 2000. Planning for Effective Faculty Development: Using
Adult Learning Strategies. In: Professional Practices in Adult Education and Human Resource Development Series. Krieger Pub. Co.

LeNoue, M., Hall, T., Eighmy, M.A., Lenoue, B.M., 2011. Adult learning. Adult Learn. 22, 4-12. http://dx.doi.org/10.1177/104515951102200201.

Lim, D.H., Morris, M.L., Kupritz, V.W., 2007. Online vs. blended learning: differences in instructional outcomes and learner satisfaction. J. Asynchronous Learn. Netw. 11, 27-42 doi:184.168.109.199.

Lourdel, N., Gondran, N., Laforest, V., Brodhag, C., Lourdel, N., Gondran, N. Laforest, V., Brodhag, C., 2005. Introduction of sustainable development in engineers' curricula: problematic and evaluation methods. Int. J. Sustain. High. Educ. 6, 254-264. http://dx.doi.org/10.1108/14676370510607223.

Lozano, F.J., Lozano, R., 2014. Developing the curriculum for a new Bachelor's degree in engineering for sustainable development. J. Clean. Prod. 64, 136-146. http:/ dx.doi.org/10.1016/j.jclepro.2013.08.022.

Lozano, R., 2006. Incorporation and institutionalization of SD into universities breaking through barriers to change. J. Clean. Prod. 14, 787-796. http:/ dx.doi.org/10.1016/j.jclepro.2005.12.010.

Lozano, R., Ceulemans, K., Alonso-Almeida, M., Huisingh, D., Lozano, F.J., Waas, T. Lambrechts, W., Lukman, R., Hugé, J., 2015. A review of commitment and implementation of sustainable development in higher education: results from a worldwide survey. J. Clean. Prod. 108, 1-18. http://dx.doi.org/10.1016/ j.jclepro.2014.09.048.

Lozano, R., Lukman, R., Lozano, F.J., Huisingh, D., Lambrechts, W., 2013. Declarations for sustainability in higher education: becoming better leaders, through addressing the university system. J. Clean. Prod. 48, 10-19. http://dx.doi.org/ 10.1016/j.jclepro.2011.10.006.

Lozano García, F.J., Gándara, G., Perrni, O., Manzano, M., Elia Hernández, D. Huisingh, D., Guillermo, F.J.L., Orietta, G., Mario, P., Dora, M., Hernández, E., Guillermo, F.J.L., Orietta, G., Mario, P., Dora, M., Hernández, E., 2008. Capacity building: a course on sustainable development to educate the educators. Int. J. Sustain. High. Educ. 9, 257-281. http://dx.doi.org/10.1108/14676370810885880.

Luppi, E., 2011. Training to education for sustainable development through elearning. In: Procedia - Social and Behavioral Sciences, pp. 3244-3251. http:/ dx.doi.org/10.1016/j.sbspro.2011.04.279.

Merriam, S.B., Caffarella, R.S., Baumgartner, L., 2007. Learning in Adulthood: a Comprehensive Guide. Jossey-Bass.

Mezirow, J., 2000. Learning as Transformation: Critical Perspectives on a Theory in Progress. In: The Jossey-Bass Higher and Adult Education Series (doi:Retrieved from EBSCO HOST).

Milana, M., Rasmussen, P., Holford, J., 2016. Societal sustainability: the contribution of adult education to sustainable societies. Int. Rev. Educ. 62, 517-522. http:/ dx.doi.org/10.1007/s11159-016-9595-0.

Morgan, D.L., 1988. Focus Groups as Qualitative Research. Sage Publications.

Mulder, K.F., Ferrer, D., Segalas Coral, J., Kordas, O., Nikiforovich, E., Pereverza, K., 2015. Motivating students and lecturers for education in sustainable development. Int. J. Sustain. High. Educ. 16, 385-401. http://dx.doi.org/10.1108/IJSHE03-2014-0033.

Mulder, K.F., Segalàs, J., Ferrer-Balas, D., Authors, F., 2012. How to educate engineers for/in sustainable development Ten years of discussion, remaining challenges. Int. J. Sustain. High. Educ. 13, 211-218. http://dx.doi.org/10.1108 14676371211242535.

Palloff, R.M., Pratt, K., 2007. Building Online Learning Communities: Effective Strategies for the Virtual Classroom, second ed. In: Technology Pedagogy and Education. Jossey-Bass.

Pérez-Foguet, A., 2008. Educative experiences through cooperation for development activities. In: Higher Education in the World 3, Higher Education: New Challenges and Emerging Roles for Human and Social Development. Palgrave Macmillan Ltd. Retrieved from: http://upcommons.upc.edu/handle/2117/25610.

Pérez-Foguet, A., Cruz López, Y., 2011. UPC's institutional transformation toward sustainability. In: Higher Education in the World 4. Higher Education's Commitment to Sustainability: from Understanding to Action. Palgrave Macmillan Ltd., pp. 301-307. Retrieved from: http://upcommons.upc.edu/handle/ $2117 / 26565$

Pérez-Foguet, A., Oliete-Josa, S., Saz-Carranza, A., 2005. Development education and engineering: a framework for incorporating reality of developing countries into engineering studies. Int. J. Sustain. High. Educ. 6, 278-303. http://dx.doi.org/ 10.1108/14676370510607241.

Pérez Foguet, A., Lobera, J., 2008. La transversalización del DHS en asignaturas técnicas: proyecto piloto en la UPC. In: IV Congreso Universidad y Cooperación al Desarrollo. Universitat Autònoma de Barcelona (UAB). Servei de Publicacions, Barcelona, pp. 1-9. Retrieved from: http://upcommons.upc.edu/handle/2117/ 8709.

Phillips, D.C., 2000. Constructivism in Education: Opinions and Second Opinions on Constroversial Issues. Yearbook of the National Society for the Study of Education ; 99th pt. 1. https://searchworks.stanford.edu/view/4377082.

Prinsloo, P., Slade, S., 2014. Educational triage in open distance learning: walking a moral tightrope. Int. Rev. Res. Open Distrib. Learn. 15 http://dx.doi.org/10.19173 irrodl.v15i4.1881.

Psillos, D., 2017. Development of a blended learning program and its pilot implementation for professional development of science teachers. In: Research on Elearning and ICT in Education. Springer International Publishing, Cham, pp. 189-200. http://dx.doi.org/10.1007/978-3-319-34127-9_14.

Psillos, D., Paraskevas, A., 2017. Teachers' views of technological pedagogical content knowledge: the case of compulsory education science in-service teachers. In: Research on E-learning and ICT in Education. Springer Internationa 
Publishing, Cham, pp. 231-240. http://dx.doi.org/10.1007/978-3-319-34127-9 17.

Pundak, D., Sabag, N., Trotskovsky, E., 2014. Accreditation of MOOCs. Eur. J. Open Distance E-Learn. 17.

Ramos, T.B., Caeiro, S., van Hoof, B., Lozano, R., Huisingh, D., Ceulemans, K., 2015. Experiences from the implementation of sustainable development in higher education institutions: environmental Management for Sustainable Universities. J. Clean. Prod. 106, 3-10. http://dx.doi.org/10.1016/j.jclepro.2015.05.110.

Richardson, J.T.E., 2009. Face-to-Face versus online tutoring support in humanities courses in distance education. Arts Humanit. High. Educ. 8, 69-85. http:// dx.doi.org/10.1177/1474022208098303.

Richardson, V., 2003. Constructivist pedagogy. Teach. Coll. Rec. 105, 1623-1640. http://dx.doi.org/10.1046/j.1467-9620.2003.00303.x.

Riviou, K., Sotiriou, S., 2017. Teachers' professional development in the theme of competence-based learning-impact and lessons learnt. In: Research on Elearning and ICT in Education. Springer International Publishing, Cham, pp. 283-297. http://dx.doi.org/10.1007/978-3-319-34127-9_21.

Rose, G., Ryan, K., Desha, C., 2015. Implementing a holistic process for embedding sustainability: a case study in first year engineering, Monash University, Australia. J. Clean. Prod. 229-238. http://dx.doi.org/10.1016 j.jclepro.2015.02.066.

Rubenson, K., 2016. Adult Learning and Education. Elsevier/Academic Press.

Sammalisto, K., Sundström, A., Holm, T., 2015. Implementation of sustainability in universities as perceived by faculty and staff - a model from a Swedish university. J. Clean. Prod. 106, 45-54. http://dx.doi.org/10.1016/ j.jclepro.2014.10.015.

Scherling, S.E., 2011. Designing and fostering effective online group projects. Adult Learn. 22, 13-18.

Schneiderman, D., Freihoefer, K., 2012. A pre- and post-evaluation of integrating sustainability curriculum by inserting Okala modules into an interior design materials and methods course. Int. J. Sustain. High. Educ. 13, 408-423. http:// dx.doi.org/10.1108/14676371211262344.

Segalàs, J., Ferrer-Balas, D., Mulder, K.F., 2010. What do engineering students learn in sustainability courses? The effect of the pedagogical approach. J. Clean. Prod. 18, 275-284. http://dx.doi.org/10.1016/j.jclepro.2009.09.012.

Segalàs, J., Ferrer-Balas, D., Svanström, M., Lundqvist, U., Mulder, K.F., 2009. What has to be learnt for sustainability? A comparison of bachelor engineering education competences at three European universities. Sustain. Sci. 4, 17-27. http://dx.doi.org/10.1007/s11625-009-0068-2.

Sen, A., 1999. Development as Freedom. Oxford Press, pp. 1-50. http://dx.doi.org/ $10.1215 / 0961754 \mathrm{X}-9-2-350$.

Svanström, M., Lozano-García, F.J., Rowe, D., 2008. Learning outcomes for sustainable development in higher education. Int. J. Sustain. High. Educ. 9, 339-351. http://dx.doi.org/10.1108/14676370810885925.

Svanström, M., Palme, U., Wedel, M.K., Carlson, O., Nyström, T., Edén, M., 2012 Embedding of ESD in engineering education -experiences from Chalmers University of technology. Int. J. Sustain. High. Educ. 13, 279-292. http://dx.doi.org/ $10.1108 / 14676371211242580$.

Swan, K., Shea, P., Fredericksen, E., 2001. Building knowledge building communities: consistency, contact and communication in the virtual classroom. J. Educ Comput. Res. 23, 359-383. http://dx.doi.org/10.2190/W4G6-HY52-57P1-PPNE.

Trimingham, R., Lazzarini, B., Pérez-Foguet, A., Noble, N., Boni, A., SierraCastañer, M., Mongera, F., Zolezzi, G., 2016. In: Leal, W., Pace, P. (Eds.), Globa Dimensions in Engineering Education: Experiences from a Collaborative Project. Teaching Education for Sustainable Development at University Level, Springer.
UNDP, 2011. Human Development Report 2011. Sustainability and Equity: a Better Future for All. Sustain. Equity a Better Futur. All (November 2, 2011). UNDPHDRO Hum. Dev. Reports 176.

UNESCO, 2015. Rethinking Education: towards a Global Common Good? (Paris).

UNESCO, 2014. Shaping the Future We Want. UN Decade of Education for Sustainable Development (2005-2014). Final Report. (Paris, France).

UNESCO, 2010. Engineering: Issues, Challenges and Opportunities for Development. UNESCO Publishing.

UNESCO, 2009. Bonn Declaration.

UNFCCC, 2015. United Nations Framework Convention on Climate Change. Adoption of the Paris Agreement, FCCC/CP/2015/L.9/Rev.1 (12/12/2015).

United Nations, 2015. General Assembly Resolution 70/1, Transforming Our World: the 2030 Agenda for Sustainable Development. A/RES/70/1 (25/09/2015).

United Nations, 2000. UN Millennium Declaration, Resolution Adopted by the General Assembly. A/RES/55/2 (18/09/2000).

Velazquez, L., Munguia, N., Platt, A., Taddei, J., 2006. Sustainable university: what can be the matter? J. Clean. Prod. 14, 810-819. http://dx.doi.org/10.1016/ j.jclepro.2005.12.008.

Velazquez, L., Munguia, N., Sanchez, M., 2005. Deterring sustainability in higher education institutions: an appraisal of the factors which influence sustainability in higher education institutions. Int. J. Sustain. High. Educ. 6, 383-391. http:// dx.doi.org/10.1108/14676370510623865.

Verhulst, E., Lambrechts, W., 2014. Fostering the incorporation of sustainable development in higher education. Lessons learned from a change management perspective. J. Clean. Prod. 106, 189-204. http://dx.doi.org/10.1016/ j.jclepro.2014.09.049.

Verhulst, E., Van Doorsselaer, K., 2015. Development of a hands-on toolkit to support integration of ecodesign in engineering programmes. J. Clean. Prod. 108, 772-783. http://dx.doi.org/10.1016/j.jclepro.2015.06.083.

von Blottnitz, H., Case, J.M., Fraser, D.M., 2015. Sustainable development at the core of undergraduate engineering curriculum reform: a new introductory course in chemical engineering. J. Clean. Prod. 106, 300-307. http://dx.doi.org/10.1016/ j.jclepro.2015.01.063.

Wang, M., Tan, S.C., Liang, J.-C., Zhang, H., 2014. Technology for higher education, adult learning and professional development. Knowl. Manag. E-Learn. 6, 203-206.

Watson, M.K., Lozano, R., Noyes, C., Rodgers, M., 2013. Assessing curricula contribution to sustainability more holistically: experiences from the integration of curricula assessment and students' perceptions at the Georgia Institute of Technology. J. Clean. Prod. 61, 106-116. http://dx.doi.org/10.1016/ j.jclepro.2013.09.010.

WCED, U.N., 1987. Our common future. World Comm. Environ. Dev. Univ. Press 400. http://dx.doi.org/10.1080/07488008808408783.

Wehrmeyer, W., Chenoweth, J., 2006. The role and effectiveness of continuing education training courses offered by higher education institutions in furthering the implementation of sustainable development. Int. J. Sustain. High. Educ. 7, 129-141. http://dx.doi.org/10.1108/14676370610655913.

Wiek, A., Withycombe, L., Redman, C.L., 2011. Key competencies in sustainability: a reference framework for academic program development. Sustain. Sci. http:// dx.doi.org/10.1007/s11625-011-0132-6.

Wlodkowski, R., 2003. Fostering motivation in professional development programs. New Dir. Adult Contin. Educ. 2003, 39-48. http://dx.doi.org/10.1002/ace.98.

Zolezzi, G., et al., 2013. Partnerships between academia and NGOs in technical studies in Italy. In: Imagining Cultures of Cooperation: Universities Networking to Face the New Development Challenges - Proceedings of the III CUCS Congress. Torino. 